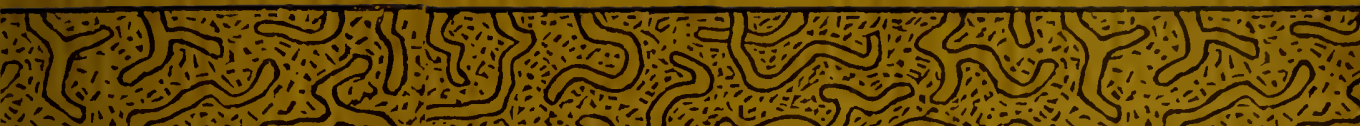
(2)

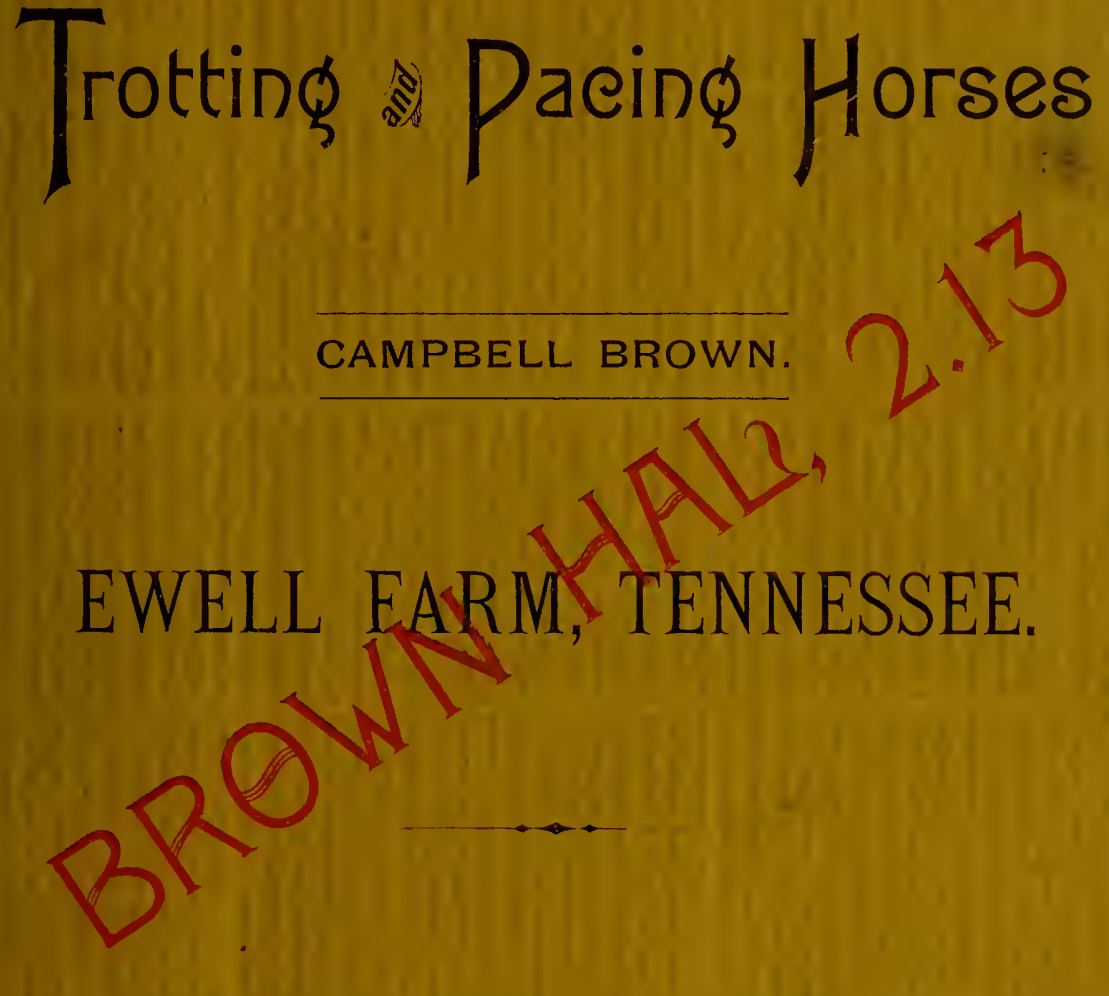

JANUARY, 1888.

र(10) 3:1) $0(0)$

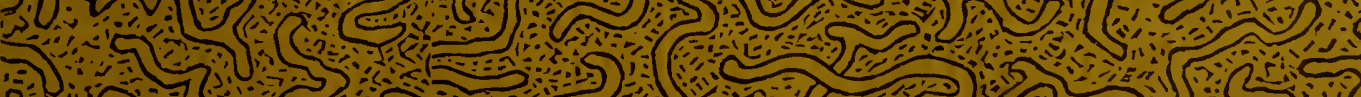
Sin BRANDON PAINT. CO. NASHVILLE. 



\title{
CATALOGUE
}

OF

\section{Trotting and Pacing Horses}

PROPERTY OF

\author{
CAMPBELL BROWN,
}

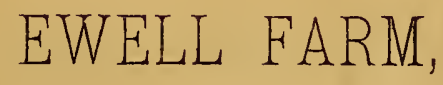

SPRING HILL, MAURY COUNTY, TENN.

EWElL Farm is on the Louisville, Nashville \& Great Southeri

Rallway, Thirty-two Miles South of Nashville. Three Daily

Trains Each Way. Ewell Station, which is also an Ex-

press and Telegraph Office, is ON The Fard. ThE

Post-office is Spring Hill, Maury County.

JANUARY, I888.

Nishville, Tenn. :

BRANDON PRINTING COMPANY.

1888. 
Digitized by the Internet Archive in 2009 with funding from

Boston Library Consortium Member Libraries

http://www.archive.org/details/catalogueoftrott00ewel 


\section{TROTTING HORSES.}

In the following pedigrees (but not always in the foot notes under the pedigrees) the names of STANDARD BRED ANIMALS are printed in small capitals, so that the reader may more readily distinguish the standard from the nou-standard crosses.

\section{STALLIONS IN USE.}

No. 1.

TENNESSEE WILKES, No. 2735. 'Trial 2.25. Bay, $15 \frac{3}{4}$ hands high; weight, 1,200 ; foaled 1880 . By GeorGE WILKES, No. 519 , record 2.22 , sire of sixty-one horses in the 2.30 list, ten of them with records below 2.20.

First dam Lizzie Hayden (full sister to Lucy Fleming, 2.24), by Peavine,

No. 513, sire of two horses in 2.30 list.

Second dam The Parish Mare (dam of Luey Fleming, 2.24; Odd Fellow,

2.31; the Karr filly, two-year-old record 2.46; Lizzie Hayden, trial

2.37, and Bud Crookes, pacing trial 2.221), by Brinker's Drennon.

Third dam Lucy, a fast pacer, by Million's Copperbottom.

At the close of 1886 George Wilkes had forty-eight trotters and four pacers in the 2.30 list, of which ten had records below 2.20 . He is credited with nine new ones in 1887, placing him well at the head of all stallions. At the close of 1886 his sons had sired nineteen 2.30 trotters. Twenty-nine others are placed to their credit in 1887, including Sable Wilkes 2.18-best three-year-old record-and Houri, $2.19 \frac{1}{2}$ at three years.

The dam of Tennessee Wilkes, Lizzie HAYDes, has a trial over a halfmile track in 2.37 with less than two months handling. She was sired by Peavine (sire of two horses in 2.30 list), by RATtLer, son of Stockbridge Chief and sire of two horses in 2.30 list, and of the dam of Keene Jim, 2.191. The dam of Peavine was by Gough's Wagner, 
thoroughbred son of Wagner and sire of the dam of Fanny Witherspoon, record $2.16_{4}^{\geq}$, and best two-mile record, $4.43 \frac{1}{2}$.

Stockbridge Chief (sire of the dam of Gloster, 2.17) by Vermont Black Hawk (sire of Ethan Allen), dam by Sir Charles (thoroughbred), soli of Duroc.

Brinker's Drennon is a noted Kentucky sire of handsome harness and saddle horses.

Tennessee Wilkes was jogged regularly through the season of 1887, and at its close was put in training. About the middle of August Mr. Bostick drove him a mile in 2.25, over my threequarter-mile track, going to the half at his ease in 1.15 and coming home in 1.10. Three or four days later pinkeye attacked every horse in my stable except Brown Hal and McEwen, and training was virtually suspended. He will be kept out of the stud this season and driven for a record.

Before pinkeye appeared in the stable his youngsters had shown some good work. Optimist, three years old, had gone a mile in 2.39, quarters in 39 secouds; Watauga, two years, quarters in 40 seconds; and Reata, two years (pacing), a quarter in 39 seconds. All will be handled next season.

Private stallion.

No. 2.

NUTHII.I, No. 4674. Dark bay horse, 153 hands high, both hind feet and heel of left fore foot white, small star; foaled 1884. By NuTw00D, No. 600, record 2.18 $\frac{3}{4}$, sire of Felix, 2.19, Nutbreaker (two jears), 2.29, and twelve other 2.30 horses.

First dam Hildegarde, by Harold, No. 413, sire of Maud S., 2.083. Second dam Betsey Trotwood, by Idol, No. 177, sire of Don, 2.22!. Third dam Pilotta, by Glasgow's Pilot, son of PrLot $J_{R}$.

Fourth dam Dairy Maid (dam of Tennessee, 2.27), by Vermont Buack HAwk, No. 5, sire of Ethan Allen.

Nutwood, by Belmont (sire of Wedgewood, 2.19, and eighteen 2.30 horses), dam Miss Russell, the dam of Maud S., 2.08 $\frac{3}{4}$, by Pilot Jr.

Harold is the sire of Maud S., 2.083, and of eighteen 2.30 horses, six of which made their records in 1887.

Glasgow's Pilot was by Pilot Jr., and his dam was by an unknown stallion out of Nancy Taylor, the grandam of Pilot Jr.

Nuthill trotted a mile, at three years old, in 2.39, and a quarter 
in 38 seconds, but his training was interrupted by pinkeye. He was exhibited five times last fall and took five first prizes, viz:

At Columbia, Tenn., at the Maury County Fair-

First as best three-year stallion in harmess.

Siveepstakes for best horse, mare, or gelding, any are, in harness.

At Nashville, at the Great T'eunessee Fair-

First as best three-year harness stallion.

First as best three-year roadster stallion.

Sweepstakes for best stallion, any age, seventeen entries.

Stamds at $\$ 50$ the season, with usual pririlege of return.

\section{9 \\ BROOD MARES AND FILLIES.}

[ARkatged in Alphabetical Order.]

No. 3 .

A LICE RUSSELL. (Standard.) Bay filly, without white, foaled May 25, 1885. By Lord Russelt, No. 4677, full brother

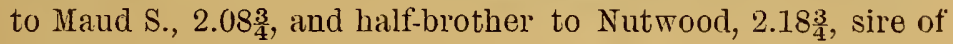
Nutbreaker, etc.

First dam Aline, by Allie West, No. 745, record 2.25: sire of Jewett, three-year trotting record $2.23 \frac{1}{2}$, and pacing record 2.14. Also of four 2.30 horses.

Second dlam Coquette (dam of Nutmeg, three-year record 2.35, Col. Stevens, four-year record 2.32, Psyche, four-year trial 2.40, and Aline, trotted at three years quarters in 40 seconds), by American Clay, sire of three 2.30 horses, and of the dams of ten others.

Third dam, by Lexington Jr. (Wade Hampton's), by Lexington.

Fourth dam, by Jenkins' Bertrand.

Fifth dam, by Hephestion.

Sixth dam, by Imp. Baronet.

Allie West, by Almont, dam by Mambrino Chief.

American Clay, by Strader's C. M. Clay, dam by Imp. Tranby. American Clay sired the dams of Ambassador, $2.21 \frac{1}{1}$, and nine 2.30 horses. His son, Magic, sired Clemmie G., $2.15 \frac{1}{2}$, and three 2.30 horses.

Alice Russell ras bred at Ewell Farm. 
No. 4.

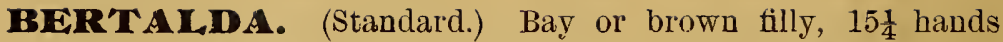
high, large star, left hind foot white; foaled May 11, 1884. Bred at Ewell Farm. By Dictator, No. 113, sire of Jay-EyeSee, 2.10.

First dam Betsey Trotwood, by Idol, No. 177, sire of Don, 2.221.

Second dam Pilotta, by Glasgow's Pilot.

Third dam Dairy Maid (dam of Tennessee, 2.27), by Vermont Black Hawk, No. 5.

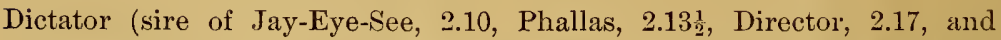
thirteen others in 2.30 list, and full brother to Dexter, 2.17 $\frac{1}{4}$, Alma, $2.28 \frac{3}{4}$, Clara, 2.291 $)$, by Rysdyk's Hambletonian, sire of forty 2.30 horses; dam by American Star, sire of the dams of thirty-four 2.30 horses.

Peck's Idol was by Mambrino Chief, dam by American Eclipse. He sired Don, 2.22! John R., 2.23, Barbara Patchen, 2.24! , and the dams of six 2.30 horses.

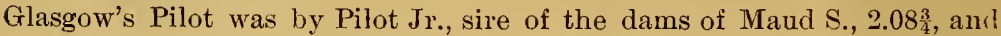
Jay-Eye-See, 2.10. The dam of Glasgow's Pilot was out of Nancy Taylor, the grandam of Pilot Jr.

Vermont Black Hawk was the sire of Ethan Allen, record, with running mate, 2.15 .

Bred to Victor Von Bismarck.

No. 5.

BETSEY TROTWOOD. (Standard.) Black mare, 16 hands high; foaled in 1870. By PEcK's ID0L, No. 177, son of Mambrino Chief.

First dam Pilotta, by Glasgow's Pilot.

Second dam Dairy Maid (lam of Tennessee, 2.27), by Vermont Bhack Hawk, No. 5 .

Peck's Idol sired Don, 2.222, John R., 2.23, and Barbara Patchen, 2.24!, and the dams of five 2.30 horses.

Glasgow's Pilot was by Pilot Jr., sire of the dams of Maud S., 2.08 $\frac{3}{4}$, and Jay-Eye-See, 2.10. The dam of Glasgow's Pilot was out of Nancy Taylor, the grandam of Pilot Jr.

Vermont Black Hawk was the sire of Ethan Allen, record, with running mate, 2.15.

Betsey Trotwood was bred by E. B. Elliston, Nashville, Tenn., 
and sold to W. R. Barry, of Gallatin, Temn., of whom I purchased her. Her son, Enterprise, has trotted, so his owner writes me, in $2.32 \frac{1}{2}$ over a half-mile track. Another son, Billy Tomkins, has trotted quarters in 35 seconds-a 2.20 gait-on my track, and a mile in 2.26; and a daughter, Ethel, at four years old, trotted quarters in 38 seconds-a 2.32 gait.

\section{PRODUCE.}

1877-br. c., Enterprise, by Enfielr.

1878 - b. f., Ethel, by Enfield.

1879-b. c., Billy Tomkins (gelded), by Enfield.

1880-bl. f., Hildegarde, by Harold.

1882--b. c., by General George H. Thomas. (Sold.)

1883-Slipped foal.

1884-br. f., Bertalda, by Dictator.

1885-b. c., Mordante, by Onward. (Sold.)

1886 and 1887 -misserl.

Bred to Egbert.

No. 6 .

CUYLERA. (Standard.) Bay mare, $15 \frac{1}{2}$ hands high, with star and left hind foot white; foaled 1880. By CuYler, No. 100, sire of Elvira, four-year record, $2.18 \frac{1}{2}$, and of five 2.30 horses. Also of the dam of the great horse Patron, threeyear record $2.19 \frac{1}{2}$; four-year record 2.18; five-year record 2.14 .

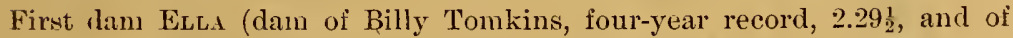
Alice Hyatt, 2.34, wimners of the Tennessee two-year-old stakes in 1884 and 1885), by ExField, No. 128, record 2.29 .

Seeond dam Milkmaid (dlam of Josephine, record 2.32), by Biggart's Rattler.

Third dam Darry Maid (dam of Tennessee, 2.27), by Trenoxt BuAck Hawk, No. 5 .

Cuyler, by Rysdyk's Hambletonian, dam Gray Rose, by Harris' Hambletonian.

Enfield, 2.29, by Rysdyk's Hambletonian, dam Julia Machree (dam of Chester, 2.2\%, and full sister to Aberdeen's dam), by American Star.

Curlera was bred by W. R. Tomkins, Gallatiu, Teno., and sold to R. C. Reynolds, by him to F. G. Buford, by him to me. She is lengthy, handsome, and finely gaited. 
PRODUCE.

1887-b. c., Navarro, by Nutwood.

Bred to Tennessee Wilkes.

No. 7.

EXIEN TEIR foaled 1882. By ENTERPRise, No. 2318, son of ENFIELd, 2.29 .

First dam Jennie B, trial 2.32, by American Ciay, No. 34.

Second dam by Blood's Black Hawk.

Third dam by Downing's Bay Messenger.

Enterprise, by Enfield, 2.29, dam Betsey Trotwood (dam of Billy Tomkins, trial 2.26), by Idol, sire of Don, $2.22 \%$.

A merican Clay sired three 2.30 horses and the dams of eleven others.

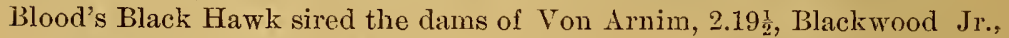

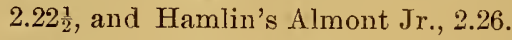

Downing's Bay Messenger sired the dam of Clark Chief.

Bred by W. E. Greenlaw, Spring Hill, Tenn. Bought of breeder.

Bred to Director, 2.17.

No. 8.

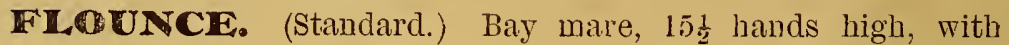
small star; foaled in 1874. By ENFreLD, No. 128, record 2.29 .

First dam Kentucky Lady, by Mambrino Pilor, No. 29, saddle record, $2.27 \frac{1}{2}$.

Second dam, by Nangatuck Black Hawk, son of Veraront Black Hawk.

Third dam, by Williamson's Pacolet (thoroughiored), son of Pacolet.

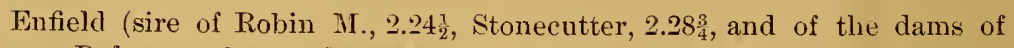
Reference, 2.29, and Billy Tomkins, $2.29 \frac{1}{2}$, and full brother to Chester, 2.27) is by Rysdyk's Hambletonian, sire of forty horses in 2.30 list. Enfield's dam, Julia Machree, is full sister to Widow Machree, 2.29, by American Star. Enfield is bred like Dictator and Startle, and is full brother in blood to Aberdeen.

Mambrino Pilot sired Hannis, 2.173, Mambrino Gift, 2.20, and five other 2.30 horses, and is grandsire of twenty-eight 2.30 hor'ses. He was by Mambrino Chief, dam by Pilot Jr. 
Naugatuck Black Hawk by Vermont Black Hawk, dam Larly Burton, by Burton's Mambrino Messenger, he by Mambrino, son of Imp. Messenger.

Flounce was bred by John Kirkman, Esq., of Nashville, of whom I bought her. Mr. Kirkman used her for several years on the road. She could trot about a 2.40 gait, or a little better, and was of unsurpassed endurance, and game.

Bred to Don Wilkes, son of George Wilkes.

No. 9.

HILDEGARDE. (Standard.) Black mare, both hind feet white, $15 \frac{3}{4}$ hands high; foaled 1880 . By HARor.D, No. 413, sire of Maud S., 2.083, and eighteen others in 2.30 list.

First dam Bersey Trotwood, by Idol, No. 177, sire of John R., 2.23, and Don, $2.22 \frac{1}{2}$.

Second dam Pilotta, by Glasgow's Pilot, son of Pilot Jr.

Third dam Dairy Maid (dam of Tennessee, 2.27), by Vernont Black H.wn, No. 5, sire of Ethan Allen.

Harold, by Rysdyk's Hambletonian, sire of forty horses in 2.30 list. His dam by old Abdallah, sire of Hambletonian.

Hildegarde was bred by J. M. Tomkins, of Gallatiu, Tenu., of whose estate I bought her as a yearling. She can trot quarters in 40 seconds, having had very little haudliug.

PRODUCE.

18st-b. c., Nuthill, by Nutwood.

$188 \tilde{-}$-Missed.

1886-b. f., Crescenz, by Tennessee Wilkes.

1887 --b. f., Nutilla, by Nutwood.

Bred to Tennessee Wilkes.

No. 10 .

IDA EI.IOTT. (Standard.) Bay filly, with ilregular White star and snip, 15 $5_{\frac{1}{2}}$ hands high; foaled April 3, 1885. By Hakold, No. 413, sire of Mand S., 2.083.

First dam Kit, by Rasselas, four-year record 2.40?, son of WoodFond MAdrBRINO, $2.21 \frac{1}{2}$.

Second dam, by Brignour, No. 77, record 2.293, son of Manbrixo Chiref.

Third dam a thoroughbred mare, bred and owned by the late Maj. Jno. R. Viley. 


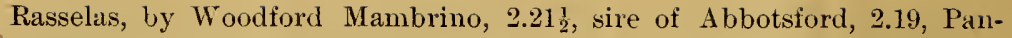
coast, $2.21 \frac{3}{4}$, and nine 2.30 horses, and son of Mambrino Chief.

First dam Jane, by Hambletonian Jr.

Second dam, by Long Island Black Hawk, sire of Prince, $2.24 \frac{1}{2}$.

Brignoli (sire of the (lams of King Wilkes, 2.221, and five others), by Mambrino Chief, dam by Woodford, sire of the dam of Woodford Mambrino.

Ida Elliott was bred by Breckiuridge Viley, Stonewall Stock Farm, Kentucky, sold to W. H. Arnold, by him to Mr. W. W. Esitill, and by him to present owner.

No. 11.

IRENE. (Standard.) Dam of Hardwood, record 2.243, trial 2.20. Brown mare, $15 \frac{3}{4}$ hands high ; foaled in 1876. By CoLumBUS, No. 1794, sire of Little Mac, $2.28 \frac{1}{2}$.

The dam of Irene was a large brown mare, with good trotting action, but of unknown blood, bought by A. J. McKimmin at Cincinnati.

Columbus, sire of Irene, was by Brown's Bellfounder, he by Imp. Bellfounder, out of Lady Allport, by Mambrino.

Irene is a mare of great power, lengthy, a fast walker and foxtrotter, and able to trot better than a four-minute gait. She was bred by A. J. McKimmin, sold by him to Col. John Overton, and by him to Col. D. B. Cooper, of whom I bought her.

\section{PRODUCE.}

1881-br. c., Hardwood, record $2.24 \frac{3}{4}$, by Blackwood Jr.

1882 - b. t., Ironette, by Blackwood Jr. (Sold.)

1883-4-5-Missed.

1886-b. or br. c., Musket, by Enfield.

1887-b. f., Fifine, by Enfield. (Sold.)

Bred to Nuthill.

No. 12 .

LADY BEIMON'T. (Standard.) Bay mare, 15:3 hands high; foaled in 1871. Bred by Harry Thompson, Clark County, Ky. By Belmont, No. 64, sire of Nutwood, 2.18 $\frac{3}{4}$, Wedgewood, 2.19, and seventeen 2.30 horses.

First dam by Ericsson, No. 130 (four-year record 2.301), sire of six 2.30 horses and grandsire of six others. 
Second ram by Vermont Brack Наwк, No. 5, sire of Etham Allen, 2.25/, Lancet, 2.272 , Belle of Saratogi, 2.29 .

Belmont, by Alexander's Abdallah, sire of Goldsnith Maid, 2.14, out of Belle (dam of McCurly's Hambletonian, five-year record 2.262 ), by Mambrino Chief, sire of Lady Thorn, $2.18_{4}^{1}$, and of the dams of sixteen 2.30 horses.

Eriesson, by Mambrino Chief (sire of Lady Thorn, 2.18!, and of five 2.30 horses), dam Mrs. Caudle, the grandam of Clark Chief, and the great grandan of Sultan.

Lady Belmont is a large, bandsome, stylish mare. She was bought at the closing-out sale of W. \& V. L. Polk, who obtained her of her breeder, and in their catalogue it is stated, upon his authority, that this mare could trot in 2.40 as a three-year-old, and her dam could trot in 2.40 .

PRODUCE.

(Since coming to Temnessee.)

1882-- b. f., Bellfield, by Enfield. (Sold.)

1883-Missed or not bred.

188t-ch. e., Beaumont, by Enfield. (Sold.)

1885-Not bred in 188t.

1886-b. Ł., Bizarre, by Tennessee Wilkes.

1887-b. c., Beltane, by Tumessee Wilkes.

Bred to Lord Russell.

No. 13.

LA GR ANDE DUCHESGE. (Standard.) Bay mare, $15 \frac{1}{4}$ hauds high; foaled in 1882. By Exfielu, No. 128, record 2.29 .

First dam Grand Duchess, by Mamimxo Patchen, No. 58.

Second dam Duchess, by Iron Duke, No. 181, son of C. M. Clay.

Third dam Belle Thornton, dam of Maubrino King, by Ewwin Forkest,

No. 49.

Fourth dam (the dam of Fisk's Mambrino Chief Jr., $2.29 \frac{1}{2}$, and he the sire of Mambrino Sparkle, 2.17, and three others in 2.30 list), by Birmingham, son of Stockholder, by Sir Archy.

Fifth dam, by Bertrand, son of Sir Archy.

Sixth dam, by Sumpter, son of Sir Archy.

Seventh dam, by Imp. Buzzard.

Mambrino Patchen (full brother of Lady Thorn, 2.181) is sire of London. $2.20 \frac{1}{4}$, and thirteen 2.30 horses. He is grandsire of Guy Wilkes, 2.15!, Jerome Turner, 2.15\%, and forty-four 2.30 performers. 
Mambrino King (by Mambrino Patchen), the "model horse" of the United States, sire of five in the 2.30 list, and sold for $\$ 10,000$, is by the sireof Grand Duchess, and out of her second dam.

Fisk's Mambrino Chief, 2.2912, sire of Mambrino Sparkle, 2.17, is by the grandsire of Grand Duchess, and nut of her third dam.

Iron Duke, by Cassius M. Clay, the sire of George M. Patehen, 2.231.

First dam, by Young Cleveland.

Second dam, by Bishop's Hambletonian, son of Imp. Messenger.

Third dam, by Commander, son of Imp. Messenger.

\section{PRODUCE.}

1886-b. f., Azara, by Tennessee Wilkes. 1887-- Misserl.

Bred to Wedgewood, 2.19.

No. 14 .

MALY M. (Standard.) Dam of Annie W., record 2.20, Andante, five-year record $2.35 \frac{1}{4}$, and McEwen, two-sear record

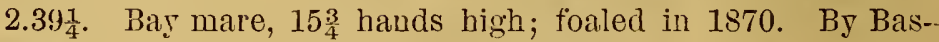
senger, a trotting horse of untraced blood.

First dam, by Hamlet (thoroughbred son of Imp. Consol).

Second dam, by George Ellintt (thoroughbred son of Imp. Leviathan).

Third dam, by Sir William.

Fourth dam, by Imp. Janus.

Mary M., her dam and her graudam, were bred by the late. Maj. Jno. L. McEwen, Franklin, Tenn. She is a remarkably stroug, handsome, lengthy mare, of excellent trotting action. All herfoals show speed.

\section{PRODUCE.}

1.875-ch. m., Annie W. (record 2.20), by Almont Jr. (Bostick's). 1880-br. m., Jessie P., by Trouble.

1881-g. m., Susie G., by Sip (pacer).

1882-ch. c., Andante, by Almont Ji. (Soll.) (Five-year record 2.35 .

1883-Missed.

1884-ch. f., Coranza, by Almont Jr.

1885-ch. c., MeEwen (two-year record 2.39! ), by MeCuidy's Hambletonian, $2.26 \frac{2}{2}$.

1886-b. f. Cassette, by Tennessee Wilkes.

1887-ch. f., Maisie, by Tennessee Wilkes.

Bred to Temnessee Wilkes. 
No. 15.

MISS D'ARCY. (Standard.) Bay, with star and snip, and hind feet white, $15 \frac{3}{4}$ hands high; foaled April 28, 1885. By Distingue, No. 2216.

First dam Lucilde Weaver, by Alcalde, No. 103.

Second dam, by ScotT's Tiomas, No. 919, record 2.21.

Third dan, by Smith Burr's W asmington, No. 332.

Fourth dam, by Downing's Bay Messenger.

Fiftlı dam, by Tom Jefferson (pacer).

Sixth dam, ly Hunt's Commodore.

Distingue, by Blackwood Jr., 2.221, dam Alanode, by Almoint, second danı Celeste (grandam of Sultan), by Mambrino Chief, third dam, own sister to Clark Chief's dan, fourth dam the dam of Ericsson.

Alealde, sire of Hylas $2.24 \frac{1}{2}$, and two 2.30 horses, was by Mambrino Chief, dam by Pilot Jr.

Scott's Thomas, record 2.21, by Gen. Geo. H. Thomas, dam by Whitehall. Washington, sire of Lady Woodruff, 2.29, by Smith Burr's Napoleon, dau by Mambrino.

Bred by A. W. Harris, Nashville, Tenn. Bought of breeder.

No. 16.

MONYCA. Brown mare, $15 \frac{3}{4}$ hands high; foaled in $1878 . \mathrm{By}$ MaMBRINo ABDALLAH, No. 1369, son of MaHBRINo PATCHEN.

First dam, by Bronaugh's Denmark Jr.

Second dam, by Whip Highlander.

Third dam, by Old Copperbottom.

Mambrino Abdaliah is full brother to Lottie Thorn, 2.27, and to Byerly Abdallah, sire of Jerome Turner, 2.15\%. His sire is Mambrino Patchen, sire of fourteen 2.30 horses and of the dams of Guy Wilkes, 2.151 , Bermuda (three years), 2.221 , and sixteen other 2.30 horses. His dam, Lady Ayres, was by Redmond's Abdallah Patchen, son of Alexander's Abdallah, and was out of that great mare, Lady Abdal-

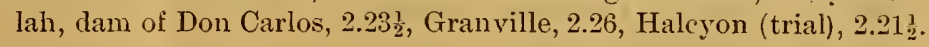

Monica was bred by Dr. L. Herr, of Lexington, Ky., at whose sale I bought her as a yearliug. She is a strong, handsome mare, and a pleasant roadster. 
PRODUCE.

1882-b. f., Monogram, by Trouble. (Sold.)

1883 -Not bred in 1882 .

1884-Not bred in 1883.

1885-b. f., Monetta, by Tennessee Wilkes. (Dead.)

1886-b. c., Monito, by Tennessee Wilkes. (Sold.)

1887--Missed. Bred to Nuthill.

No. 17.

MUDRA. (Standard.) Brown mare, no marks, $15 \frac{1}{2}$ hands high; foaled in 1874 . By Sentinel, No. 280, record 2.29, sire

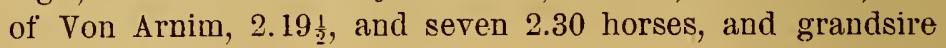
of ten others.

First dam Constance, by Hamlet, No. 160 (record 2.36), son of Volunteer. Second dam, by Long Island Black Hawk.

Sentinel is full brother to Volunteer, sire of St. Julien, $2.11_{4}^{\frac{1}{2}}$, and twentyfive 2.30 horses, and grandsire of forty-one. Sentinel died at eleven years of age, just as he began to attain popularity as a sire.

Hamlet (sire of A. V. Pantlind, record 2.20, and four 2.30 horses, and of the pacer Truro, record $\left.2.22 \frac{3}{4}\right)$, by Volunteer, dam by Hulse's Hickory.

Long Island Black Hawk, sire of two 2.30 horses and grandsire of fifteen others, was by Andrew Jackson, founder of the Clay family of trotters, out of Sally Niller, by Tippoo Saib.

Mudra was bred by Edward Thorne, 'Thornedale, Duchess County, New York. She is a large, strong, bandsome, and finely-gaited mare, and an excellent breeder.

\section{PRODUCE.}

(Owned at Ewell Farm.)

1885-b. f., Mudrette, by Bostick's Almont, Jr. 2.29. (Sold.)

1886-b. f. (dead), by Bostick's Almont Jr.

1887-br. f., Mudarra, by Brown Hal, 2.13.

Bred to Baron Wilkes, 2.241. 
No. 18.

MYRTLE. (Standard.) Bay, no marks except black spot on jaw, $15 \frac{1}{2}$ hands high; foaled 1878. By ENFILD, No. 128, record

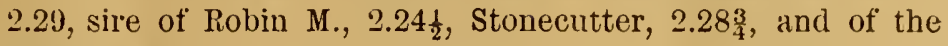
dams of Reference (three years), 2.29, and Billy Tomkins (four years), $2.29 \frac{1}{2}$.

First dam Minette, by Ekicsson, No. 130, four-year record $2.30 \frac{1}{2}$, wire of Eric, four-year record 2.28 , and five in 2.30 list.

Second dan Minnie Clyde, by Brignoli, No. 77, record 2.293.

Third dan, by Gano, sire of the dam of Lady Thorn, 2.181.

Fourth dam, hy Potomac.

Fifth dam, by Baronet.

Ericsson, sire of six horses in 2.30 list, is by Mambrino Chief, dam Mrs. Caudle, the grandam of Clark Chief.

Brignoli, $2.29 \frac{1}{4}$, sire of the dams of five 2.30 horses, is by Mambrino Chief, sire of Lady Thorn, 2.18 , and six others in 2.30 list.

Myrtle was bred at Ewell Farm. She is a smooth, strong, and speedy mare, of excellent temper.

\section{PRODUCE.}

1882-b. t., Myrtilla, by Trouble. (Sold.)

1883-b. f., Laurel, by Brown Hal, 2.13.

1884-b. c., Balzan, by Tennessee Wilkes. (Solk.)

1885-b. f., Starlight, by Tennessee Wilkes.

1886-b. f., Myrtis, by Temnessee Wilkes.

1887-b. c., Kingston, by Tennessee Wilkes.

Bred to Tennessee Wilkes.

No. 19.

ORIANA. (Standard.) Bay mare, 15 hands high, foaled in 1882. By ENField, No. 128, record 2.29 .

Dam by BAY Woonford, No. 754 .

Enfield, record 2.29, is own brother to Chester, 2.27 , and to Mercury, sire of Chester F., 2.27. He is sire of Robin, 2.242, Stonecutter, 2.283, and of the dams of Reference (three years), 2.29, and Billy Tomkins (four years), 2.29?.

Bay Woodford, by Edwin Forrest, sire of Billy Hoskins, 2.26, out of Misnouri, by Mambrino Chief, sire of Lady Thorm, 2.181. 
Oriana was bred by J. K. Orr, Mt. Pleasant, Tenn., of whom I bought her. He also bred her dam.

Bred to Brighton, son of Harry Clay.

No. 20.

WIDOW MALONE. Bay mare, $15 \frac{1}{4}$ handis high, no marks; foaled in 1874. By Enfield, No. 128, record 2.29, sire of Robin M., $2.24 \frac{1}{2}$.

First dam, sister to Maud Williams, trial 2.26, by Second Hiawatha. Second dam Tena, dam of Maud Williams, by Mambrino Messenger. Third dam, by Young Jefferson (pacer).

Fourth dam, by Hunt's Commodore.

Enfield, by Rysdyk's Hambletonian (sire of forty horses with records of 2.30 or better); first dam Julia Machree (full sister to Widow Machree, 2.29), by Seely's American Star. His breeding is identical with that of Dictator, Startle, and Aberdeen.

Second Hiawatha, sire of Maud Williams, was by Hiawatha (thoroughbred), out of a mare by Mambrino Messenger.

Mambrino Messenger (sire of Gen. Geo. H. Thomas, and grandsire of Scott's Thomas, 2.21) was by Mambrino Paymaster, sire of Mambrino Chief and out of Lady Messenger, by Coffin's Messenger.

Widow Malone was bred by J. K. Miller, Gallatin, Temu., and passed from him to W. \& V. L. Polk, of whom I bought her. She is a handsome, stylish mare, quite speedy and a good roadster.

PRODUCE.

\section{(At Ewell Farm.)}

1884-b. f., Wenonah, by Tennessee Wilkes. (Sold.)

1885-b. f., Watauga, by Tennessee Wilkes.

1886-b. c., Harry Lorrequer, by Tennessee Wilkes.

1887-b. c., Jack Hinton, by Tennessee Wilkes.

Bred to Tennessee Wilkes. 


\title{
THREE-YEAR-OLD FILLIES.
}

\author{
No. 21.
}

REATA. Bay tilly, foaled May 10, 1885. By 'l'exresser WILKES, No. 2735 .

First dam Lizzie Moore (sister to Little Brown Jug, 2.113, and Brown Hal, 2.13), by Gilsson's Tom Hal.

Second dam Lizzie, by John Netherland (saddle horse).

Third dam, by John Hal, son of John Eaton.

For extended pedigree see Lizzie Moore, No. 65.

Reata was bred by the Clovernook Stock Company, of Spring Hill, Tenu., and bought by me at their closing-out sale in October, 1885. She was driven about six weeks as a two-year-old, paced a quarter in 39 seconds and was then attacked by pinkeye aud turned out.

No. 22.

S'TARIIGHT. (Standard.) Bay filly, with star and snip, hind legs white to ankles; foaled March 21, 1885. By TexNESSEE WILKES, No. 2735.

First dam Myrtee, by Enfield, No. 128, record 2.29.

Second dam Minette, by Ericsson, No. 130, record $2.30 \frac{1}{2}$.

Third dam Minnie Clyde, by Brignour, No. 77, record 2.293.

For Myrtle's pedigree see No. 18.

Bred at Ewell Farm. Just broken to harness. Promising.

No. 23.

WА TAUGA. (Standard.) Bay filly, little white on left hind ankle; foaled February 23, 1885 . By Tennessee Wilkes, No. 2735 .

First dam Widow Malone, by Enfield, No. 128, record 2.29.

For extended pedigree see Widow Malone, No. 20.

Watauga was bred at Ewell Farm. She trotted a quarter as a two-year-old, early in the season, in 40 seconds, was then attacked bs pinkeye and turned out.

2 


\section{TWO-YEAR-OLD FILLIES.}

No. 24.

AZARA. (Standard.) Solid dark bay; foaled May 9, 1886. By Tennessee Wilkes, No. 2735.

First dam La Grande Duchesse, by Enfield, No. 128, record 2.29.

Second dam Grand Duchess, by Mambrino Patchen, No. 58.

Third dam Duchess, by Iron Duke, No. 181, son of C. M. Clay.

Fourth dam Belle Thornton, dam of Mambrino King, No. 1279, by Edwin Forrest.

Fifth dam (the dam of Fisk's Mambrino Chief Jr., 2.29: the sire of Mambrino Sparkle, $2.17 \frac{1}{4}$, and three others in the 2.30 list), by Birmingham, son of Stockholder, by Sir Archy.

For extended pedigree see La Grande Duchesse, No. 13.

Bred at Ewell Farm.

No. 25.

AZIOL.A. Bay filly, right hind leg white above ankle, small star in face; foaled May 10, 1886. By Tennessee Wilkes, No. 2735.

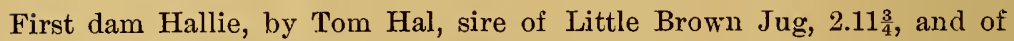
Brown Hal, 2.13.

Second dam Highland Mary, by Shoo Fly (pacer).

Third dam Lilie May, by Prince Pulaski, sire of Mattie Hunter, 2.123.

Shoo Fly was a fast pacer, by Kramer, also a fast pacer. Kramer, by McMeens' Traveler, pacer, and grandsire of Joe Bowers Jr., 2.18.

I farmed the dam of Aziola from Capt. G. W. Campbell, of Carter's Creek, Tenn.

No. 26.

BIZARRE. (Standard.) Bay filly, with star in face, no other white; foaled April 14, 1886. By Tennessee Wilkes, No. 2735.

First dam Lady Belmont, by Belmont, No. 64, sire of Nutwood, $2.18 \frac{3}{4}$.

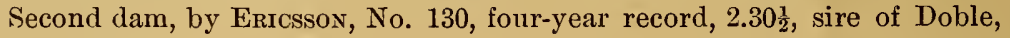
2.28 . 
Third dam, by Vermont Busck Hawк, No. 5, sire of Ethan Allen.

For details of pedigree see Lady Belmont, No. 12.

Bred at Ewell Farm.

No. 27 .

CASSE'T'TE. Bay filly, with both hind ankles white; foaled March 18, 1886. By Tennessee Wilkes, No. 2735.

First dam Mary M. (dam of Annie W., 2.20), by Bassinger.

Second dam, by Hamlet (thoroughbred), son of Imp. Consol.

For extension of pedigree see Mary M., No. 14 .

Bred at Ewell Farm.

No. 28.

CRESCENZ. (Standard.) Bay filly, with small star, left fore foot and right hind foot white; foaled April 26, 1886. By Tennessee Wilkes, No. 2735.

First dam Hildegarde, by Harold, No. 413, sire of Maud S., $2.08 \frac{3}{4}$. Second dam Betsey Trotwood, by Idol, No. 177, sire of Don, $2.22 \frac{1}{2}$.

For extended pedigree see Hildegarde, No. 9.

Bred at Ewell Farm.

No. 29.

FIN ALE. (Standard.) Bay filly, no marks; foaled May 9, 1886. By Tennessee Wilkes, No. 2735.

First dam Gray Fanny, dam of Stonecutter, 2.28 $\frac{3}{4}$, by.Pilot Jr., No. 12. Second dam, by John Democrat (pacer).

Third dam, by a son of Copperbottom.

Pilot Jr. sired the dams of Nutwood, Maud S., and Jay-Eye-See.

Bred at Ewell Farm.

No. 30 .

MYRTIS. (Standard.) Bay filly, right hind heel white, right hind ankle roan or gray; foaled April 27, 1886. By TennesSEE WILKES, No. 2735. 
First dam Myrtle, by Enfield, No. 128, record 2.29.

Second dam Mrnette, by Ericsson, No. 130, four-year record $2.30 \frac{1}{2}$.

Third dam Minnie Clyde, by Brignoli, No. 77, record 2.293.

Fourth dam, by Gano, sire of the dam of Mambrino Patchen.

For extended pedigree see Myrtle, No. 18.

Bred at Ewell Farm.

\section{YEARLING FILLIES.}

No. 31.

AMAMINE. (Standard.) Dark chestnut filly, no white; foaled April, 1887. By Tennessee Wilkes, No. 2735.

First dam Young Ada, by Skeptic, No. 1507.

Second dam Ada Brungard (dam of Optima, three-year record 2.49, winner at two and three years old, and four-year trial 2.22), by Black Hawk Rattler.

Third dam Gamma, by Frank MeNairy.

Fourth dam, a fine saddle mare, a pacer.

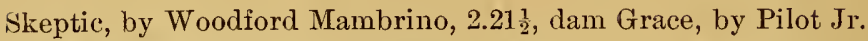

Black Hawk Rattler, by Riggart's Rattler, out of Dairymaid (dam of Tennessee, 2.27), by Vermont Black Hawk.

I farmed the dam of Amadine from Dr. J. T. S. Thompson, Spring Hill, Tenn.

No. 32.

EMER ALD. (Standard.) Bay filly; foaled April, 1887. By Tennessee Wilkes, No. 2735.

First dam Empress, by ENTerprise, No. 2318.

Enterprise by Enfield, 2.29, dam Betsey Trotwood (No. 5 of this catalogue), by Idol, son of Mambrino Chief.

I farmed the dam of Emerald from Dr. J. T. S. Thompson, of Spring Hill, Tenn. 
No. 33.

ENFILETA. (Standard.) Bay filly, with star and one white foot; foaled April, 1887. By ENFIELD, No. 128, record 2.29.

First dium Proxy, by Alaont JR., No. 1764, reeord 2.29.

Fecond dam by Avalanche (thoroughbred), son of Lexington.

I farmed the dam of Enfileta from Berry W. Hamilton, Franklin, 'Tenn.

No. 34.

FIIRTATION. (Standard.) Bay filly, right hind foot white; foaled February 28, 1887 . By Tennesse Wilkes, No. 2735 .

First dam Jenny Pruit (dam of Flash, record 2.19: trial 2.17 and sold for $\$ 8,000)$, by Sir Alfred (saddle horse).

Second dam by Driver (pacer).

Bred at Ewell Farm.

No. 35 .

MAISIE. (Standard.) Chestnut filly, with stripe in face and hind legs white above ankles; foaled May 8, 1887. By TeNNESSEE WILKES, No. 2735.

First dam Mary M. (dam of Annie W., 2.20, Andante, 2.35 $\frac{1}{4}$, McEwen, two year old, $\left.2.39 \frac{1}{4}\right)$, by Bassenger.

Second dam by Hamlet, thoroughbred son of Imp. Consol.

For extended pedigreé see Mary M., No. 14.

Bred at Ewell Farm.

No. 36 .

MATHILDE. (Standard.) Bay filly; foaled May, 1887. By Tennessee Wilkes, No. 2735.

First dam Mag Thomas by Gen. Geo. H. Thomas, No. 530.

Second dam Carrie T., by Alsont, No. 33.

Third dam by Alexander's AbDallah, No. 15.

Fourth dam by Robt. Bruce, son of Clinton. 


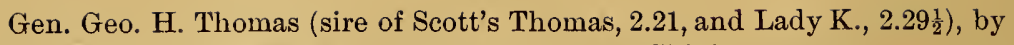
Mambrino Messenger, dam by Mambrino Chief.

Almont (sire of thirty-two 2.30 horses), by Alexander's Abdallah, dam by Mambrino Chief.

Alexander's Abdallah (sire of Goldsmith Maid, 2.14), by Rysdyk's Hambletonian.

I farmed Mag Thomas of J. B. Briggs, Esq., Russellville, Ky. She was driven a trial as a three-year-old, over my track, in 2.36 .

No. 37.

IUSCA TEL. Bay filly; foaled May 10, 1887. By Tennessee WILKES, No. 2735.

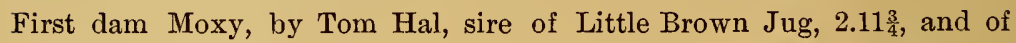
Brown Hal, 2.13.

Second dam Trix Esmond, by ERICsson, No. 130, four-year record $2.30 \frac{1}{2}$.

Third dam by Morgan Whip.

For extended pedigree see Moxy, No. 70.

Bred at Ewell Farm.

No. 38.

NUTILI.A. (Standard.) Bay filly, no marks; foaled May 10, 1887. By Nutw0od, No. 600, record 2.18 $\frac{3}{4}$.

First dam Hildegarde, by Harold, No. 413.

Second dam Betsey Trotwood, by Idol, No. 177.

Third dam Pilotta, by Glasgow's Pilot.

Fourth dam Dairymaid (dam of Tennessee, 2.27), by Vermont Black Hawk, No. 5 .

For notes on pedigree see Hildegarde, No. 9.

Bred at Ewell Farm.

No. 39.

PICCOLA. (Standard.) Chestnut filly, with blaze in face and hind ankles white; foaled June 8, 1887. By Tennesse Wilkes, No. 2735.

First dam Puss Enterprise, by EnTERPrise, No. 2318, son of Enfield, 2.29. Second dam Puss Denmark, by Harris' Denmark.

Third dam, by Warfield's Sidi Hamet. 
Enterprise was by Enfield, 2.29, out of Betsey Trotwood, by Idol. See Betsey Trotwood, No. 5, for extension of pedigree.

Puss Denmark was one of the handsomest and most highly finished saddle mares and prize-winners ever in Tennessee. It is said that she was never beaten in a show-ring. At Nashville and Columbia she won in her class and in sweepstakes, and at Columbia a special premium for best mare and three of her foals. Her pedigree, as stated here, is that given by her previous owner, Dr. Rife, of Kentucky, to Capt. Gibson, breeder of Puss Enterprise, and is doubtless correct.

Bred at Ewell Farm.

\section{STALLIONS AND STALLION COLTS.}

No. 40 .

McEWEN, No. 47rg. Two-year record 2.391. Chestnut colt, $15 \frac{1}{2}$ hands high; foaled in 1885 . By MCCURDY's HAMBLETONIAN, No. 1644, five-year record 2.26.

First dam Mary M. (dam of Annie W., 2.20, Andante, five-year record

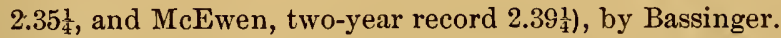

Second dam, by Hamlet (thoroughbred), son of Imp. Consol.

For extended pedigree see Mary M., No. 14.

McEwen was bred by Jas. McEwen, of Franklin, Tenn., and bought of his breeder. He won the Hermitage stakes for twoyear-olds at Nashville, taking the second and third heats in $2.41 \frac{1}{4}$, 2.391. Eight started. Two days later he was second in the Stal-

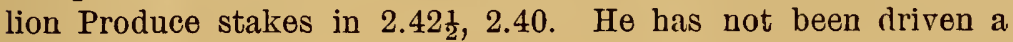
mile since, but has trotted a half in 1.14, and a quarter in 36 seconds.

No. 41.

FLINT, No. 5904. Bay colt, dim star in forehead, right hind foot white to ankle; foaled March 26, 1886. By TennesSEE WILKES, No. 2735.

First dam Jenny Pruit (dam of Flash, record 2.19⿺辶, trial 2.17, and sold for $\$ 8,000)$, by Sir Alfred (saddle horse).

Second dam, by Driver (pacer).

Bred at Ewell Farm. 
No. 42.

HARRY LORREQUER, No. 5905. Bay colt, both hind legs white to ankle, heel of left fore foot white; foaled March 15, 1886. By Tennessee Wilkes, No. 2735.

First dam Widow Malone, by ENfield, No. 128, record 2.29.

Second dam sister to Maud Williams, trial 2.26, by Second Hiawatha. Third dam Tena, dam of Maud Williams, by Mambrino Messenger.

"Fourth dam, by Young Jefferson (pacer).

Fifth dam, by Hunt's Commodore.

For details of pedigree see Widow Malone, No. 20 .

Bred at Ewell Farm.

No. 43.

MARMORA," No. 5909. Brown colt, hind feet white nearly to aukles; foaled June $3,1886$. By TenNessen Wilkes, No. 2735.

First dam Mimos , by Enfreld, No. 128, record 2.29.

Second dam Constance Carey (full sister to the dam of John F. Phelps Jr., 2.26), by Conscript, brother to AMERICAN CLAY, and sire of the dams of Flora Wilkes (pacer), $2.19 \frac{1}{2}$, and two 2.30 horses.

Third dam MAG Ferguson (dam of Piedmont, 2.17 , Almont Eagle, 2.27, and of the dam of John F. Phelps Jr., 2.26), by Mambrino Chief, No. 11.

Fourth dam, by Gray Eagle.

I farmed the dam of this colt from L. L. Losey, Esq., Nashville, Tenn.

No. 44.

MUSKET, No. 5609. Brown colt, light hind heel white; foaled April 30, 1886. By ENField, No. 128, record 2.29.

Dam Irene (dam of Hardwood, $2.24 \frac{3}{4}$ ), by Columbus, No. 1794, sire of Little Mack, 2.28.

Bred at Ewell Farm. 
No. 45.

BELTANE. (Standard.) Bay colt, both hind ankles white; foaled June 2, 1887. By 'Tennessee Wilkes, No. 2735.

First dam Lady Beliont, by Belmont, No. (it.

For extended pedigree see Lady Belmont, No. 12.

Bred at Ewell Farm.

No. 46 .

JACK MINTON. (Standard.) Bay colt, with stal and left hind foot white; foaled February 25, 1887. By Tennessee WiLkES, No. 2735.

First dam Widow Malone, by Enfield, No. 128, record 2.29.

For extended pedigree see Widow Malone, No. 20.

Bred at Ewell Farm.

No. 47 .

KINGSTON. (Standard.) Bay colt, no marks; foaled April 7, 1887. By Tennessee Wilkes, No. 2735.

First dam Myrtee, by Enfield, No. 128, record 2.29 .

For extended pedigree see Myrtle, No. 18.

Bred at Ewell Farm.

No. 48.

MORISCO. Bay colt, with small star and hind foot white; foaled April 13, 1887. By Tennessee Wrukes, No. 2735.

First Dam Lizzie Moore, (sister to Brown Jug, 2.113 2.13), by Gibson's Tom Hal.

Second dam Lizzie, by John Netherland (saddle horse).

Third dam, by John Hal, son of John Eaton.

For extended pedigree see Lizzie Moore, No. 65.

Bred at Ewell Farm. 
No. 49.

NAVARRO. (Standard.) Light bay colt, with small star; foaled April, 1887. By Notw00D, No. 600, record 2.183.

First dam Cuylera, by Cuyler, No. 100, sire of Elvira, $2.18 \frac{3}{4}$.

Second dam EllA (dam of Alice Hyatt, 2.34, and Billy Tomkins, four-year record 2.291 , winners of the Tennessee two-year-old stakes in 1884 and 1885), by ENFIELD, record 2.29 .

Third dam Milkmaid (dam of Josephine, record 2.32), by Biggart's Rattler. Fourth dam Dairy MaId (dam of Tennessee, 2.27), by Vermont Black Hawk, No. 5.

Cuyler (sire of Elvira, four-year record 2.18 horses; also of the dam of the great colt, Patron, three-year record $2.19 \frac{1}{2}$, four-year record 2.18, five-year record 2.14), by Rysdyk's Hambletonian, dam Gray Rose, by Harris' Hambletonian.

Enfield, 2.29, by Rysdyk's Hambletonian, dam Julia Machree (dam of Chester, 2.27, and full sister to Aberdeen's dam), by American Star.

Bred at Ewell Farm.

No. 50 .

ROCOCO. (Standard.) Chestnut colt with narrow blaze and snip, and both hind ankles white; foaled April 4, 1887. By Tennessee Wilkes, No. 2735.

First dam Roulette, by Enfield, No. 128, record 2.29.

Second dam Chatwood, by BLAckwoon JR., No. 380, record 2.221.

Third dam Chieftain's Daughter, by Chieftain, $2.35 \frac{1}{2}$.

Fourth dam Lee Bell, by Lee, son of Mambrino Chief.

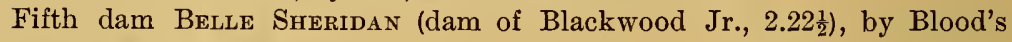
Black Hawk.

Sixth dam; by Moreland's Highlander.

Seventh dam, by Virginia Whip.

Enfield, by Rysdyk's Hambletonian, sire of forty horses in 2.30 list; dam Julia Machree, full sister to Widow Machree, 2.29, by American Star. Enfield is bred like Dictator and Startle, and is full brother in blood to Aberdeen.

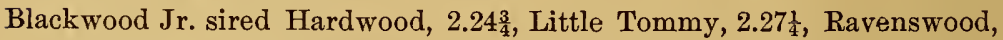
public trial, 2.26.

Chieftain (Overton's) was by Clark Chief, sire of the dams of Phallas, $2.13 \frac{3}{4}$, Majolica, 2.15, etc.

Lee Belle was a remarkable show mare. She won first premium at St. Louis Fair in a ring of sixty-five roadsters, mares, and geldings, getting every vote. 


\section{PACING HORSES.}

In this catalogue all animals by trotting-bred sires are classed as trotters, and those by pacing-bred sires as pacers, the blood of the dams and the natural gait being, for the time, ignored. Some arbitrary line of division was necessary and this seemed the most simple, although the result is not always satisfactory. For instance, the filly, Reata, by Temnessee Wilkes, out of Lizzie Moore, is found among the trotters; but she is a pacer, her dam a pacer and pacing-bred, and the second aud third dams of Tennessee Wilkes are pacing-bred, so that Reata has more pacing than trotting bluod. Laurel, by Brown Hal, is among the pacers, though her tirst, second, and third dams are by standard trotters.

But pacing blood has done so much for the trotter, and so many trotting-bred horses are natural pacers, that no sharp line of division can fairly be drawn. It may not be uninteresting to examine these two points very brietly and imperfectly.

Blue Bull, a pacing stallion, is second ouly to George Wilkes as a sire of trotters, having to his credit fifty-six 2.30 trotters and pacers, five of them with records below 2.20. Smuggler, a pacing stallion, held, for eight years, the best trotting stallion record, riz: $2.15_{4}^{1}$. Bonesetter, a pacing-bred stallion, still heads all trotting stallions in number of heats (88) trotted belor 2.30. Again, there are but four stallious up to this date with records below 2.20 that have sous or daughters also with records below 2.20. Bonesetter. 2.19 , is one of these, his daughter, Flash, having a record of $2.19 \frac{1}{2}$.

No trotter has yet been able to equal the three consecutive

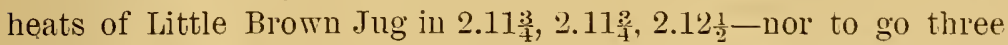
heats so near the top of his speed, and in so nearly the same time.

A hasty examination of the 2.30 list, as it stood at the end of 1885 , shows that twenty pacing-bred sires have contributed to it one hundred and six 2.30 trotters, ten of them with records of 2.20 or better.

In Wallace's short list of "great brood mares," no less than twenty-three are pacing-bred, and fire others are out of pacingbred dams. Of these trenty-eight mares tive hare produced three or more 2.30 trotters. 
During the past year the pacers have advaneed so rapidly in popular favor that it seems useless to make any extended argument on their behalf. Their merits as road-horses are pretty generally recognized, and the demand for them for this purpose is in excess of the supply.

But it may not be out of place to speak of the opportunities and performances of the pacing-bred horses of Tennessee. 'Ten years ago there was hardly a training-stable for trotters and pacers in Tennessee, and to-day there are very few. Yet in that time the State has sent out Little Brown Jug, 2.113; ; Mattie Hunter, 2.123;

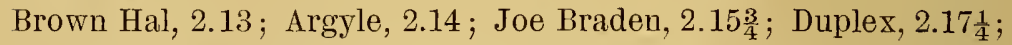

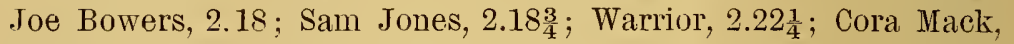

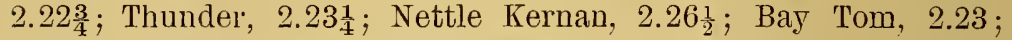

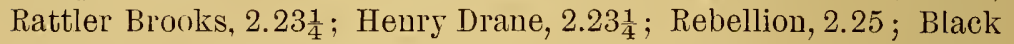

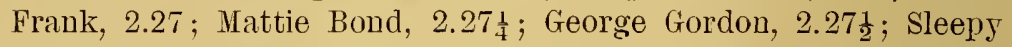
Lize, 2.29 ; Mattie Harris, 2.291. Moreover, the following Tennessee-brerl trotters are of pacing blood: Bonesetter, 2.19; Flash,

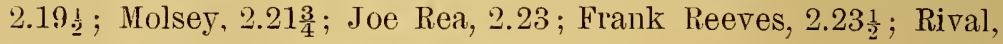
2.29 ; Blue Jay, 2.29 ; Fred Neil, $2.29 \frac{1}{2}$. 


\section{PACING STALLIONS.}

No. 51 .

BROWN MAL. Brown stallion, with wine-colored muzzle and flanks, $15 \frac{3}{4}$ hands high; foaled 1879. Pacing record 2.13, trotting trial 2.21; own brother to Little Brown Jug, 2.113. By Tom Hal (Moore's or Gibson's).

First dam Lizzie (dam of Little Brown Jug, 2.113; Brown Hal, 2.13, and Cooper's Jug, three-year trial 2.28), by John Netherland (pacer).

Second dam Blackie, by John Hal, son of John Eaton.

Third dam Old March, by Young Conqueror, son of Lafayette.

Fourth dam the Conrad Hicks Mare, of untraced blood.

Tom Hal was probably (for there is some doubt as to his paternity) by Kittrell's Tom Hal, a large bay paeer, bred in Bourbon County, $\mathrm{Ky}$., by Simeon Kirtley and brought to Tennessee by Maj. M. B. Kittrell. As to his dam there is no question whatever. She was a roan mare named Julia Johnson, by Adams' Stump (pacer), son of the thoroughbred horse, Stump-the-Dealer, and he by Timoleon. Tom Hal sired Little Brown Jug, 2.11 $\frac{3}{4}$, Brown Hal, 2.13, and the dam of Blue Jay (trotter), 2.29. His son, Locomotive, sired Rebellion, 2.241.

John Netherland, by Taylor's Henry Hal, son of Kittrell's Tom Hal.

John Hal has no Tom Hal blood in him, being by a horse claimed to be thoroughbred, out of a pacing-bred mare.

Brown Hal is the joint property of M. C. Campbell and Campbell Brown. He was bred by R. H. Moore, the breeder of Little Brown Jug, and sold as a weanling to Ozro N. Fry, of Marshall County, Tenu., of whom we bought him in December, 1881. Brown Hal trotted a mile trial over my track (a little over three-quarters of a mile, and with one bad turn in it) in the latter part of May, 1885, in 2.21. In August, 1885, he was put to pacing, and in October paced a mile over the same track in $2.18 \frac{1}{2}$, and repeated in $2.16 \frac{1}{2}$. A week later I timed him a quarter in $31 \frac{1}{4}$ seconds. In the summer of 1886 Brown Hal started in four races-at Pittsburgh, Detroit, Cleveland, and Rochester-winning all, pacing seventeen heats without a single break, and making a record of $2.17 \frac{1}{2}$. Of the seventeen heats he won twelve, was second three times and third twice. The slowest heat won by him was paced in 2.19 , the slowest that he lost was in $2.18 \frac{3}{4}$. In 1887 , after a full season in 
the stud, he was started at Lexington, Ky., on August 31, to beat Maxie Cobb's record, for a cup. He succeeded at the first trial, making his present record of 2.13. Of this performance Wallace's Monthly for December speaks as follows:

BRown HAL.-We have until now inadvertently omitted to refer to the great performance this season of Brown Hal, the brother of Little Brown Jug. As every one knows, this greatest of pacing stallions has beaten Maxie Cobb's trotting record of 2.131 by just one-quarter of a second. We think the three consecutive heats of his brother, Little Brown Jug, in $2.11 \frac{3}{4}, 2.11 \frac{3}{4}, 2.12 \frac{1}{2}$, a better record than the single dash of Johnson in $2.06 \frac{1}{4}$, and the two pacing sons of Gibson's Tom Hal are the pacing kings indeed.

Stands at $\$ 100$, with usual privilege of return.

No. 52.

MASKER. Brown stallion, with star and snip, 16 hands high, weight 1,200 Ibs; foaled April 25, 1884. By Brown Hal, 2.13,

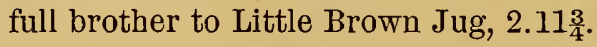

First dam Mattie Bethel, by Moore's Slasher (pacer).

Mattie Bethel has paced quarters in 33 seconds.

Masker is almost the counterpart of his sire, but will be a decidedly larger horse. He is beautifully gaited and promising.

Stands at $\$ 25$, with usual privilege of return.

\section{PACING BROOD MARES.}

No. 53.

BANQUETTE. Black mare, $15 \frac{1}{2}$ hands high; foaled August 8, 1883. By Brown Hal, 2.13.

First dam Bonnie Annie, by Omega, son of Traveler (pacer).

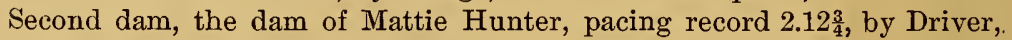
son of Vermont Morgan (sire of Golddust).

For extended pedigree see Bonnie Annie, No. 54.

Banquette was bred at Ewell Farm. She is handsome, very strong, and a fast natural pacer.

Bred to Stranger, son of Goldsmith Maid, 2.14: 
No. 54.

BONNIE ANNIE. Half-sister to Mattie Hunter, 2.123. Chestnut mare, $15 \frac{1}{2}$ hands high; foaled 1869. By Omega, son of Traveler (pacer).

First dam, the dam of Mattie Hunter, $2.12 \frac{3}{4}$, by Driver, son of Vermont Morgan (sire of Golddust).

Second dam, a fast-pacing mustang mare.

Omega, the sire of Bonnie Annie, was a fine saddle horse, $15 \frac{1}{2}$ hands high, by Traveler, grandsire of Joe Bowers Jr., pacing record 2.18, Geo. Gordon, pacing, 2.27 , and Dick Hunter, trial 2.21. The damı of Omega was by Hark, a thoroughbred son of Imp. Consol.

The grandam of Bonnie Annie was a fast-pacing black mustang mare, brought from Texas by the late George P. Webster, Esq., of Maury County, Tenn., and sold by him to the late Rev. Isaac Milner. In 1862 Mr. Milner was stationed in North Alabama, and while there bred this black mare to Driver, a son of Vermont Morgan (sire of Golddust), owned by Mr. W. Malone, of Cherokee, Alabama. The produce was a chestnut mare, the dam of Mattie Hunter, 2.123, of Dick Hunter, trial 2.21, of Ned Hunter, trial 2.22, and of Bonnie Annie, trial 2.53. All these were bred by Mr. Milner.

Bonnie Annie was sold by George Milner, Esq. (son of Rev. I. Milner), to Hon. Henry Cooper, of whom I bought her when eleven years old. She had been used as a rockaway mare and driven in a trot. With thirty-six days' handling she paced a mile over a half-mile track in 2.53. This satistied me of her speed, and she was put to breeding.

\section{PRODUCE.}

1882-ch. c., Banquo (gelded), by Trouble. (Sold.)

1883-bl. f., Banquette, by Brown Hal.

1884-Missed.

1885-ch. c., A rizona Wilkes, by Tennessee Wilkes. (Sold and dead.) 1886-ch. c., Octoroon, by Tom Hal. (Sold.)

1887-b. f., Masquerade, by Masker.

Bred to Masker.

No. 55.

CoOsA. Bay roan mare, 15 hands high; foaled 1881. By Moore's Locomotive (pacer), sire of Henry Drane, 2.231.

Dam Annie (dam of Billy Kedron, pacer, record 2.2914), by Willy Thompson (pacer). 
Moore's Loeomotive, by Loeomotive, dam by Whirlwind (pacer). Second dam by Pointer's Slasher. Third dam by Nolan's Copperbottom.

Locomotive (sire of Rebellion, 2.25), by Tom Hal (sire of Brown Hal), dam by Rock, a fast quarter horse. Locomotive was probably quite as fast as Brown Hal or Little Brown Jug, but was injured by an ignorant trainer.

Willy Thompson, by Thompson's Traveler (pacer), son of MeMeens' Traveler, grandsire of Joe Bowers, 2.18.

Coosa was bred by ,Guy Parkes, Kedron, Tenn. Her dam pro-

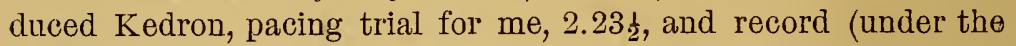
name of Billy Kedron) of $2.29 \frac{1}{4}$, made in 1887 . Coosa is a firstclass saddle mare and a fast natural pacer; strong, spirited, and active.

Bred to Brown Hal.

No. 56.

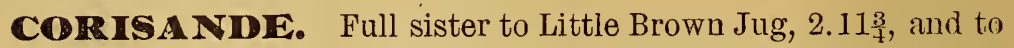

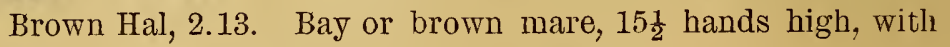
star; foaled spring of 1877. By Tom Hal.

First dam Lizzie, by John Netherland (pacer).

Second dam Blackie, by John Hal (saddle horse), son of John Eaton.

Third dam Old Mareh, by Young Conqueror, son of Lafayette.

Fourth dam the Conrad Hieks mare.

John Netherland by Taylor's Henry Hal, he by Kittrell's Tom Hal.

John Hal has no Hal blood in him. His sire is elaimed to be thoroughbred; his dam, Melinda, a fine saddle mare, by Whale, a horse brought from North Carolina by Geo. Reavis, and also claimed to be thoroughbred.

Young Conqueror's breeding is not traced.

Bred by R. H. Moore, Culleoka, Tenn. A natural pacer and saddle mare, with excellent natural trotting action.

Bred to Pocahontas Boy.

No. 57.

DAISY MILLER. Red roan mare, $15 \frac{3}{4}$ hands high; foaled spring of 1879. By Tom Hal, sire of Brown Hal, 2.13.

First dam Emma, by Kittrell's Tom Hal.

Second dam Emma, by MeMeens' Traveler. 
Tom Hal (Gibson's or Moore's), sire of Brown Hal and Brown Jug, was probably by Kittrell's Tom Hal.

Tom Hal (Kittrell's) was bred by Simeon Kirtley, of Bourbon County, Ky., and brought to Tennessee by Maj. M. B. Kittrell.

MeMcens' Traveler sirerl Joe Bowers (pacer), 2.32, and his sons sired Joe Bowers J1., 2.18, Sam Jones, 2.18 3 , Billy White (trotting), 2.29, and the dams of Joe Braden, $2.15_{4}^{3}$, and George Gordon, 2.272 .

Daisy Miller was bred by Mrs. S. J. Pickens, Mooresville, 'Tenu., who also bred her dam and her grandam. I bought her of Mrs. Pickens' son-in-law, Mr. J. T. Lowry, Lynnville, 'l'enn. Although so strongly paciug-bred she cannot pace, but walks asd trots fast.

Bred to Tennesse Wilkes.

No. 58.

DOLLY MOUNT. Bay mare, $15 \frac{1}{2}$ hands high; foaled in 1882. By Underwood's Mountain Traveler.

First dam by Gibson's John Dillard Jr.

Underwood's Mountain Traveler, by Pointer's Slasher (pacer), dam by McMeens' Traveler, second dam by Blackman's Sir Charles.

Pointer's Slasher, by Old Mountain Slasher (pacer), dam Zephyr, own sister to Thompson's Traveler, sire of Sam Jones, 2.18\%.

Gibson's John Dillard Jr. by John Dillard, sire of the dams of Phil Thompson, 2.161, and eight 2.30 trotters.

Dolly Mount was bred by Silas Jones, sold by him to W. R. Brown, of Neapolis, Tenn., and by him to me.

Bred to Brown Hal, 2.13.

No. 59.

ETMEI B. Two-year trial (trotting) over my track in exact.ly three minutes. Bay mare, 15 hands high, star, no other white; foaled in 1882. By Tom Hal, sire of Little Brown Jug, $2.11 \frac{3}{4}$.

First dam Tampa, by Thompson's Traveler (pacer).

Second dam, by Nolan's Old Copperbottom (pacer).

Third dam, by Ridley's Medly.

Fourth dam, by a horse called Eclipse.

Fifth dam, brought with him from Kentucky in 1832 , by the late Mr. William Witt, of Spring Hill, Tenn. 
Thompson's Traveler was by McMeens' Traveler (grandsire of Joe Bowers Jr., 2.18), out of a mare by Blackman's Sir Charles, thoroughbred son of Sir Charles, by Sir Archy.

The dain of this filly was a noted premiuun saddle mare and fast pacer.

Ethel B. was bred by W. H. Brown, of Spring Hill, Teno. As a two-year-old she trotted a mile, on my three-quarter mile track, in exactly three minutes. She is a natural pacer.

Bred to Tennessee Wilkes.

No. 60 .

MLLLIE. Roan mare, with star aud two white feet; foaled in 1880. By Tom Hal, sire of Brown Hal, 2.13.

First dam Highland Mary, by Shoofly (pacer).

econd dam Lilie May, by Frince Pulaski, sire of Mattie Hunter, 2.123.

hoofly was a speedy pacer by Kramer, son of MeMeens' Traveler. McMeens' Traveler is grandsire of Joe Bowers, 2.18, Sam Jones, 2.18 $\frac{3}{4}$.

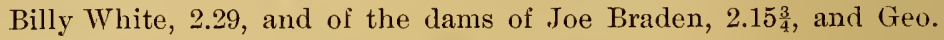
Gordon, 2.27!

Hallie was bred by T. A. Orr, Mooresville, Tenn., and bought hy me of Geo. W. Campbell, Carter's Creek, Tenn.

Bred to Tennessee Wilkes.

No. 61 .

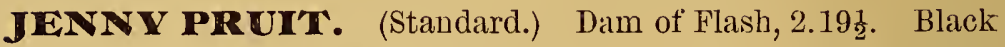
mare, 15 hands high; foaled in 1872. By Sir Alfred (saddle horse).

First dam, by Driver (pacer).

Sir Alfred was by a horse of the same name, but of untraced pedigree, brought to Marshall County about the year 1855 from East Tennessee. This first Sir Alfred was a large, handsome harness horse. His son was a bay, out of a saddle mare, and was a good saddle horse.

Jenny Pruit was bred by S. C. Pruit, Lewisburg, Marshall County, of whom I bought her, and is a handsome, highly finished mare, of fine natural trotting action. 
PRODUCE.

1878-bl. m., Flash, record 2.191, by Bonesetter. (Folrl for $\$ 8,000$.)

1884-b. c., Flight, by Collins' Bay Tom. (Sold.)

1885--Missed.

1886--b. c., Flint, by Tennessee Wilkes.

1887-b. f., Flirtation, by Tennessee Wilkes.

Bred to Brown Hal.

No. 62 .

KATE BRADEN. Bay mare; foaled 1884. By Bay Tom, pacing record 2.23, trial 2.15 ; sire of Fred Neil, trotting record $2.26 \frac{3}{4}$.

First dam Lula Braden (dam of Joe Braden, pacing record $2.15_{4}^{3}$ ), by a son of McMeens' Traveler.

Second dam, a black pacing mare of untraced bloorl.

Bay Tom's pedigree has never been fully traced. He sired Fred Neil (trotting), 2.263, and Bay Tom Jr. (pacing), 2.321. The latter horse sired Duplex, 2.17!

Kate Braden was bred by Messrs. A. N. Akin and E. F. Geers, of Columbia, Tenn., of whom I bought her.

Bred to Brown Hal.

No. 63.

KATYDID. Roan mare, with narrow blaze in face, $15 \frac{3}{4}$ hands high; foaled April, 1882. By Cooper's Jug (three-year trial 2.28, pacing), own brother to Little Brown Jug, 2.113, and Brown Hal, 2.13.

First dam, by Pointer's Slasher (pacer).

Cooper's Jug made a trial in his three-year-old form of 2.28, driven by $\mathrm{Mr}$.

John Bostick. He was then sold and taken to California.

Pointer's Slasher, by Old Mountain Slasher, dam Zephyr, own sister to Thompson's Traveler, sire of Sam Jones, 2.18 $\frac{3}{4}$.

Katydid was foaled the property of W. E. Babb, Carter's Creek, Tenn., of whom I bought her.

Bred to Tennessee Wilkes. 
No. 64.

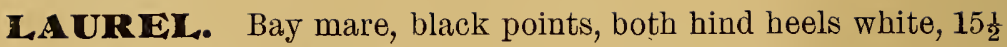
hands high; foaled May 12, 1883. By Brown Hal, 2.13.

First dam Myrtue, by Enfield, 2.29.

Second dam Minetre, by ERIcsson, fuur-year record $2.30 \frac{1}{2}$, sire of Eric, four-year record 2.28, and of four others in 2.30 list.

Third dam Minnie Clyde, by Brignol, $2.29 \frac{3}{4}$.

Fourth dam, by Gano, sire of the dam of Lady Thorn, $2.18_{4}^{1}$.

Fifth dam, by Potomac.

Sixth dam, by Baronet.

For notes on pedigree see Myrtle, No. 18.

Laurel was bred at Ewell Farm. She has paced quarters as a four-year-old in $37_{\frac{1}{2}}$ seconds, and will be in training this year.

No. 65 .

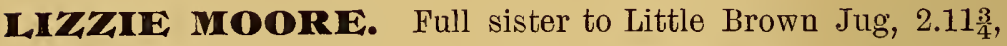
and to Brown Hal, 2.13. Bay mare, 15 hands high, with star; foaled April 23, 1880 . By Tom Hal.

First dam Lizzie, by John Netherland (pacer).

Second dam Blackie, by John Hal (saddle horse), son of John Eaton.

Third dam Old March, by Young Conqueror, son of Lafayette.

Fourth dam the Conrad Hicks mare.

John Netherland, by Taylor's Henry Hal, he by Kittrell's Tom Hal.

John Hal has no Hal blood in him. His sire is said to be thoroughbred; his dam, Melinda, ajfine saddle mare, by Whale, a horse brought from North Carolina by Geo. Reavis, and claimed to be thoroughbred.

Young Conqueror's breeding is not traced.

Bred by R. H. Moore, Culleoka, Tenn. A natural pacer and saddle mare, with excellent natural trotting action.

PRODUCE.

1885 -b. f., Reata, by Tennessee Wilkes.

1886-Missed.

1887-b. c., Morisco, by Tennessee Wilkes.

Bred to Tennessee Wilkes. 
No. 66.

LUL.A BRADEN. Dam of Joe Braden, pacing record

2.15:3. Black mare, with small star, 15 hands high; foaled about 1868. By a son of Mclfeens' Traveler, tlam a black pacing mare of untraced blood.

This mare was bred by Sky Boyd, of Marbert P. 0., Giles County, 'Tennessee, who also bred her sou, Joe Braden, and sold both animals to Joe Braden, of Pulaski, Tenn. Boyd is a small farmer, careless as to the pedigrees of his horses, and keeping no records. He knows positively that Lula Braden was by one of two stallions, half-brothers, the Frank Carter Traveler or the Browulow 'Traveler (both sons of the old McMeens' Traveler, grand sire of Joe Bowers, 2.18), but cannot say by which one. Her dam was a mare of unknown breeding, a natural pacer. Lula is a natural pacer, with high withers, sloping shoulders, drooped rump, neat, bony head, and good mane and tail.

\section{PRODUCE.}

1877-b. g., Joe Braden, pacing record $2.15 \frac{3}{4}$.

1884-b. f., Kate Braden, by Bay Tom, record 2.2:3.

1885-Missed to Bay Tom.

1886-Missed to Brown Hal.

1887-br. or ro. f., Lulita, by Brown Hal.

Bred to Brown Hal.

No. 67.

MA'T'TE BETHEL. Brown or black mare, tan muzzle, 16 hands high. Bred by McCord C. Denton, Culleoka, Maury County, Tenu.; foaled in April, 1872. By Moore's Slasher (pacer).

Dam, a pacer of unknown blood.

Mattie Bethel is a very fast pacer. Col. 'T. W. Keesee told me he had repeatedly timed her quarters in 33 seconds-a 2.12 gaitover Mr. Ed. Geers' half-mile track, and Mr. Geers said she had pulled him as fast as he had ever ridden. She had been stiffened by the use of heavy shoes in an attempt to make her trot, before coming into Mr. Geers' hauds. 


\section{PRODUCE.}

1884-br. c., Masker, by Brown Hal.

1885--br. c., Melton, by Tennessee Wilkes. (Gelded and sold.)

1886-br. f., Mattie Hal, by Brown Hal. (Sold.)

1887-br. c., by Brown Hal. (Dead.)

Bred to Brown Hal.

No. 68 .

MAXIE P. Trial 2.26. Bay mare, with large star, and left hind leg white above ankle; $15 \frac{3}{4}$ hands high; foaled 1881. By Prince Pulaski, sire of Mattie Hunter, 2.12 $\frac{3}{4}$.

First clam a very fast roadster, of untraced blood.

Maxie P. was bred by Dr. A. T. Boyd, Bigbyville, Maury County, Tenn. Her trial of 2.26 was made for Mr. E. F. Geers, who writes me: "I am satisfied that I have ridden at a two-minute gait behind her."

Bred to Pocahoutas Boy.

No. 69.

MINNIE MORTON. Dark blue roan mare, 16 hands high; foaled in 1880. By Tom Hal, sire of Brown Hal, 2.13.

First dam Susie Brooks, by Brooks, sire of Bonesetter, 2.19.

second clain Bell, by Henry Hal, son of Kittrell's Tom Hal.

Third dam Old Roan, by Cox's Traveler, son of McMeens' Traveler.

Kittrell's Tom Hal was probably the sire of Gibson's Tom Hal (sire of Little Brown $\mathrm{Jug}, 2.11 \frac{3}{4}$ ). Hetwas certainly the grandsire of the clam of Little Brown Jug and Brown Hal.

McMeens' Traveler was grandsire of Joe Bowers, 2.18, Sam Jones, 2.183, Billy White (trotting), 2.29, and of the dams of Joe Braden, 2.153, and George Gordon, 2.27 $\frac{1}{2}$.

Minuie Morton was bred by D. B. Pickens, Mooresville, Tenu., who also bred her dam and grandam. He sold Minnie to his son, H. Pickens, of whom I bought her.

Bred to Brighton, son of Harry Clay. 
No. 70 .

MOXY. Blue roan mare, 15血 hands high; foaled 1883 . By Tom Hal, sire of Little Brown Jug, 2.113, and of Brown Hal, .13 .

First clan Trix Esmonrl, by Ericsson, four-year record 2.301.

Second dam, by Morgan Whip.

Third dam the Old Hunt Premium Mare (twenty-nine preniums, and never beaten in a show ring), by Scott's Highlander.

Fourtl dam Fanny, by Brown Highlander.

Fifth dam, by Bertrand.

Sixth dam Old Spot, by Hampton's Twig.

Seventh dam, by Imp. Bedford.

Trix Esmond is the dam of Mr. A. H. Robinson's filly, Beatrix, that trotted my track as a three-year-old in $2.34 \frac{1}{2}$, and as a four-year-old in 2.29. Her sire, Ericsson, had the best four-year record for fourteen years, has six colts in the 2.30 list, and is by Mambrino Chief, out of the grandam of Clark Chief.

Moxy was bred by W. \& V. L. Polk, of whom I bought her.

\section{PRODUCE.}

1887-b. f., Museatel, by Tennessee Wilkes.

Bred to Tennessee Wilkes.

No. 71.

ORELIA. Red roan mare, with star; foaled spring of 1882. By Tom Hal, sire of Little Brown Jug, 2.113.

First dam, by Black Hawk Rattler.

Black Hawk Rattler, by Biggart's Rattler (sire of the dams of Lady Suell, 2.231, Alameda Maid, $2.27 \frac{1}{2}$, and Nellie Webster, $\left.2.28 \frac{3}{4}\right)$, out of Dairy Maid (dam of Tennessee, 2.27), by Vermont Black Hawk.

Orelia was bred by Burton Coleman, Carter's Creek, Tenn., of whom I bought her.

Bred to Montrose (saddle horse), sou of Montrose. 
No. 72 .

OSYKA. Bay mare, with small snip and dim star in forehead, left hind leg white, $15 \frac{1}{4}$ hands high; foaled June 2, 1884. By Brown Hal, 2.13, brother to Little Brown Jug, 2.11 $\frac{3}{4}$.

First dam Bessie Taylor, by Enfield, 2.29.

Second dam Minnie Clyde, by Brignoli, 2.293.

Third dam, by Gano (sire of the dam of Laty Thorn, 2.181).

Fourth dam, by Potomac.

Fifth dam, by Baronet.

Enfield (sire of Robin M., $2.24 \frac{3}{4}$, and Stonecutter, $2.28 \frac{3}{4}$, and full brother to. Chester, 2.27) is by Rysdyk's Hambletonian, sire of forty horses in 2.30 list. Enfield's dam, Julia Machree, is full sister to Widow Machree, 2.29, by American Star. Enfield is bred like Dictator and Startle, and is full brother in blood to Aberdeen.

Brignoli (Mambrino Prince) is by Mambrino Chief. He sired the dams of six horses in 2.30 list.

Osyka was bred at Ewell Farm. She is of fair size, speedylooking, and a natural pacer.

Bred to Wedgewood, 2.19.

No. 73.

QUEEN BRES Bay mare, no white; foaled April, 1881. By Prince Pulaski, sire of Mattie Hunter, 2.12 $\frac{3}{4}$.

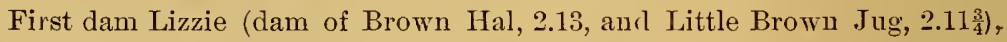
by John Netherland (pacer).

Second dam Blackie, by John Hal, son of John Eaton.

Third dam Old March, by Young Conqueror, son of Lafayette.

Fourth dam, the Conrad Hicks mare.

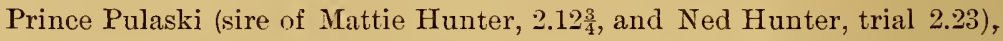
was a rery handsome chestnut, 16 hands high, a fine saddle horse, and winner of many premiums. He was bought out of a government corral in Nashville at the close of the war, and his blood could never be traced. In appearance he strongly resembles the Travelers, but no kinship to them can be proved.

John Netherland, by Taylor's Henry Hal, son of Kittrell's 'Tom Hal. Gibson's Tom Hal, sire of Brown Hal, was probably also by Kittrell's Tom Hal.

John Hal had no Hal blood in him. His sire was stated to be thoroughbred; his dam, Melinda, a fine saddle mare.

Young Conqueror's blood is untraced. 
Queen Bess was bred by R. H. Moore, breeder of Brown Hal and Little Brown Jug, and bought of him.

PRODUCE.

1886-ch. f., Chestnut Be]l, by Brown Trigham. (Sold.) 1887-Missed.

Bred to Brown Hal.

No. 74.

SALUDA. Roan mare, 16 hands high, narrow blaze in face, left hind foot white; foaled spring of 1882. BF C'ooper's Jug (pacing trial 2.28 at three years), own brother to Brown Jug, 2.11 $\frac{3}{4}$, and Brown Hal, 2.13.

First dam, by Bob Batey, son of Joe Bowers, 2.32.

Second dam, by Joe Bowers, 2.32.

Cooper's Jug was driven, by Mr. John Bostick, a mile in 2.28 in his threeyear-old form, for his owner, Col. Cooper. He was then sold and carried to California.

Bob Batey, by Joe Bowers, son of McMeens' Traveler, and sire of Joe Bowers Jr., 2.18.

Saluda was bred by Sam T. Brown, Columbia, Tenn., and bought of him.

Bred to Tennessee Wilkes.

No. 75 .

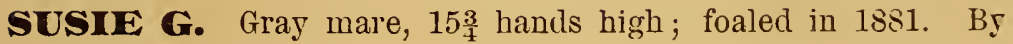
Scipio (fast pacer).

First dam MARY M., dam of Annie W., 2.20.

For extended pedigree see Mary MI., No. 14.

Scipio, or Sip, was a very fast pacer, owned by John Fitzgerald, Thompson's Station, Tenn., and sired by Reckless, son of Clipper. He had a trial of 2.26, but could show a 2.20 gait or better. Clipper, his grandsire, was a son of Kittrell's Tom Hal.

Susie G. was bred by Jas. P. McEwen, breeder of Annie W., and sold by him to me. She is a stylish and rather speedy trotter, with no disposition to pace. 


\section{PRODUCE.}

1886-gr. f., Tosa, by Enfield, 2.29. (Sold.)

1887-br. f., Racola, by Brown Hal, 2.13.

Bred to Brown Hal.

No. 76.

TACOM. Brown mare, 16 hands high, with star and suip, and both hind feet white; foaled in 1882. By Tom Hal, sire of Brown Hal, 2.13.

First dam Julia, by Mahan's Traveler.

Mahan's Traveler, by 'Thomas' Traveler, by McMeens' (or the Old) Traveler, grandsire of Joe Bowers Jr., 2.18, Sam Jones, 2.183, etc.

Tacoma was bred by W. T. Edwards, and passed through the hands of T. C. Leneave and W. R. Tomlinson to present owner.

Bred to Montrose, son of Montrose.

No. 77.

ZARA. Roan mare, with star; scant 15 hands, very lengthy; foaled in 1881. By Tom Hal, sire of Little Brown Jug, 2.11 $\frac{3}{4}$.

First dam, by Pointer's Slasher (pacer).

Pointer's Slasher, by Old Mountain Slasher (a noted pacer and saddle horse in his day), dam Zephyr, sister to Thompson's Traveler, sire of Sam Jones, 2.18 $\frac{3}{4}$.

Zara was bred by Albert Campbell, of Spriug Hill, Tenn., of whom I bought her.

Bred to Tennessee Wilkes. 


\section{PACING FILLIES.}

No. 78.

GLIDE. Light bay filly, with both hind heels white; foaled May 23, 1885. By Tom Hal, sire of Browu Jug, 2.11 3 .

First dam Hattie, by Dudley's Snow Heel (saddle horse).

Second dam Annie, by Pointer's Slasher (saddle horse).

Third dam Ganma, by Frank MeNairy.

Fourth dam Skip, a watural pacer and fine saddle mare.

Dudley's Snow Heel (also known as Knight's Snow Heel) was a son of Knight's Tom Hal.

Pointer's Slasher by Mountain Slasher (pacer), out of Zephyr, by McMeens' Traveler, grandsire of Joe Bowers Jr., 2.18.

I farmed the dam of Glide from John F. Wade, Spring Hill, Tenn.

No. 79.

LUCX W. Bay filly, with large crescent in forehead; no other white. By Tom Hal, sire of Brown Jug, 2.113.

First dam Annie, by Gibson's John Dillard Jr., son of John Dillard (saddle horse).

Second dam, by Thompson's Traveler (pacer), sire of Sam Jones, 2.1S

John Dillard Jr. was by John Dillard, sire of the dams of Phil Thomp-

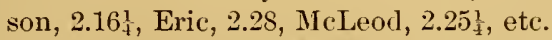

Thompson's Traveler, by McMeens' Traveler, sire of Joe Bowers, 2.32, and grandsire of Joe Bowers Jr., 2.18, dam by Blackman's Sir Charles, thoroughbred son of Sir Charles.

I farmed the dam of Lucy W. from Capt. H. P. Pointer. Spring Hill, Tenn.

No. 80 .

NANCY ROLFE. (Standard.) Bay filly; foaled July 3,

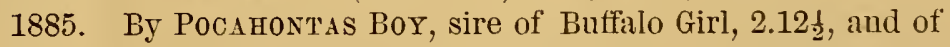
ten 2.30 pacers and trotters.

First dam Lady Gerighty, by Bute BuLL, sire of fifty-three trotters and pacers under 2.30.

Second dam, by Shropshire's Tom Hal.

Third dam, by Copperbottom (of Indiana). 
Pocahontas Boy was sired by Tom Rolfe, sire of the pacers Sleepy Tom $2.12 \frac{1}{2}$, Gem, $2.13 \frac{1}{4}$, and of four trotters with records between $2.21 \frac{1}{4}$ and: 2.25 .

The pedigree of Lady Gerighty is stated as given by her breeder, Mr. Gerighty, of Rushville, Ind. I do not know what particular Copperbottom and Tom Hal are meant.

Nancy was bred by Mr. J. H. Clark, Elmira, N. Y., of whom I bought her. Though a standard-bred trotter, she is entirely of pacing blood. Pocahontas Boy sired, out of mares by Blue Bull, the trotters, Highland Mary, 2.26, Highland Maid, 2.29 $\frac{1}{2}$, and Polka Dot, 2.28 , and the pacer, Princess, $2.19 \frac{1}{4}$.

\section{No. 81 .}

AMORA TA. Bay filly, with star, and left hind foot white; foaled April 21, 1886. By Tom Hal, sire of Little Brown Jug, - 2.113 $\frac{3}{4}$ and Brown Hal, 2.13.

First dam Annie, by Jameson's John Dillard Jr. (pacer).

Second dam Lucy, by Black Hawk Rattler (trotter).

Third dam Fanny, by 'Thomas' Traveler (pacer).

Fourth dam Emma, by Sam Walker (quarter horse).

Fifth dam the "Pony Mare," by Old Bowie (quarter horse).

Jameson's John Dillard Jr. (also called Revenue), by Gibson's John Dillard Jr., son of John Dillard (sire of the dams of Phil Thompson, $\frac{1}{4}$, McLeod, $2.25_{4}^{1}$, etc.). The dam of the Jameson Dillard was by Pointer's Slasher, second dam by Thompson's Traveler, sire of Sam Jones, $2.18_{4}^{3}$.

Black Hawk Rattler, by Biggart's Rattler (sire of the dams of four 2.30 trotters), dam Dairymaid (dam of Tennessee, 2.27), by Vermont Black Hawk.

'Thomas' Traveler, by McMeens' Traveler, sire of Joe Bowers, 2.32, and grandsire of Joe Bowers Jr., 2.18, and of Sam Jones, 2.18 $\frac{3}{4}$.

I farmed the dam of Amorata fiom Jno. F. Wade, Esq., Spring Hill, Tenn.

No 82.

CA NOSSA. Brown tilly, with star, both hind feet and left fore foot white; foaled March 17, 1886. By Tom Hal, sire of Brown Hal, 2.13.

First dam Zephyr, by Jameson's John Dillard Jr., grandson of John Dil-lard. 
Second dam 'Tampa, by 'Thompson's Traveler (pacer).

Third dam, by Nolan's Old Copperbottom (pacer).

Fourth dam, by Ridley's Medley.

Fifth dam, by a horse ealled Eclipse.

Sixth dam, lronght by him from Kentucky in 1832, by the late Mr. William Witt, of Spring Hill, Tenn.

Jameson's John Dillard Jr. (also called Revenue), by Gibson's John Dillard Jr., son of John Dillard (sire of the dams of Phil Thompson, 2.16!, McLeod, 2.25⿺, etc.). The dam of the Janeson Dillard was by Pointer's Slasher, second dam by Thompson's Traveler, sire of Sam Jones, $2.18_{4}^{3}$.

Thompson's Traveler (sire of Sam Jones, $2.18_{4}^{3}$ ), by McMeens' Traveler (grandsire of Joe Bowers Jr., 2.18), dam by Sir Charles (Blackman's), son of Sir Charles.

I farmed the dam of Canossa from W. H. Brown, of Spring Hill, Tenn.

No. 83.

VILLETTE. Light bay filly, with large star; foaled April 30, 1886. By Brown Hal, 2.13.

First dam Sweepstakes, by Knight's Snow Heel (saddle horse).

Second dam Kit, by McMeens' Traveler, grandsire of Joe Bowers Jr., 2.18, and Sam Jones, $2.18_{4}^{3}$.

Snow Heel (Knight's or Dudley's), by Knight's Tom Hal, son of Kittrell's Tom Hal.

McMeens' Traveler by Sugg's Stump, son of Stump-the-Dealer (thoroughbred), son of Timoleon. Joe Bowers, the only one of his get ever trained, made a record of 2.32, and sired Joe Bowers Jr., 2.18. Other sons of Traveler sired Sam Jones, 2.18 the dam of Joe Braden, $2.15_{4}^{3}$.

I farmed the dam of Villette from Capt. H. P. Pointer, Spring Hill, Tenn.

No. 84.

LULITA. Dark gray or roan filly, with very large star and snip, left fore foot and both hind feet white; foaled March 30, 1887. By Brown Hal, 2.13. 
Dam Lula Braden (dam of Joe Braden, 2.15 $\frac{3}{4}$ ), by a son of McMeens' Traveler.

For details of pedigree seẻ Lula Braden, No. 66 .

Bred at Ewell Farm.

No. 85 .

MASQUERADE. Bay filly, small star, no other white; foaled in 1887. By Masker, son of Brown Hal, 2.13.

First dam Bonnie Annie, by Omega, son of Traveler (pacer).

Second dam, the dam of Mattie Hunter, 2.123, by Driver, son of Vermont Morgan (sire of Golddust).

For exteuded pedigree see Bonnie Annie, No. 54, and Masker, No. 52.

Bred at Ewell Farm.

No. 86 .

MUDARRA. Brown filly, right hind foot white; foaled May 15, 1887. By Brown Hal, 2.13.

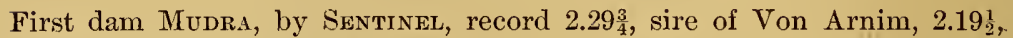
and seven 2.30 horses.

Second dam Constance, by Hanlet, son of Volunteer.

Third dam, by Long Island Black Hawk.

For extended pedigree see Mudra, No. 17.

Bred at Ewell Farm.

No. 87.

SOLACE. Bay filly, with small star; foaled April 26, 1887. By Brown Hal, 2.13.

First dam Susie G., by Scipio (or Sip) (pacer).

Second dam Mary M., dam of Annie W., 2.20.

For extended pedigree see Mary M., No. 14.

Scipio (or Sip), was a very fast pacer, owned by John Fitzgerald, Thompson's Station, Tenn., and sired by Reckless, son of Clipper. He had a trial in 2.25 , but could show a 2.20 gait or better. Clipper, his grandsire, was a son of Kittrell's Tom Hal. 


\section{PACING COLTS.}

No. 88.

BOST ANTE. Bay colt, with small star, both hind feet white; foaled March 8, 1886. By Brown Hal, 2.13.

First dam Yellow Mag, by Slasher (Pointer's) (pacer).

Second dam Fox, by Driver (pacer).

Third dam, by McMeens' 'Traveler (pacer), grandsire of Sam Jones, 2.183, and Joe Bowers Jr., 2.18.

Pointer's Slasher was a fast and liandsome pacer, by Mountain Slasher; dam, the great premium mare, Zephyr, by McMeens' Traveler, and she own sister to Thompson's Traveler, sire of Sam Jones 2.183.

Driver was a fast-pacing black horse, owned by the late Allen T. Nolan, of Williamson County, Tenn.

McMeens' Traveler was a strong, handsome chestnut, a fast pacer, by the thoroughbred Stump-the-Dealer, by Timoleon. The dam of McMeens' Traveler was a fast saddle mare, of untraced blood.

Bred at Ewell Farm.

No. 89.

CLERUR NE. Brown colt, foaled April, 1887. By Brown Hal, 2.13.

First dam Daisy, by Cunningham's Prince (pacer).

Cunningham's Prince was a large and fast bay horse by Kramer, son of McMeens' Traveler, sire of Joe Bowers, 2.32, and grandsire of Joe Bowers Jr., 2.18, and Sam Jones, 2.183.

Bred by Col. H. A. Brown, Cleburne, Tenn., and bought of him. Cleburne's dam is a very fast natural pacer.

No. 90 .

GRANDEE. Roan colt, with black legs; foaled April 30, 1886, By Tom Hal, sire of Brown Hal, 2.13.

First dam, by Planeroid (thorouglibred), son of Planet. Second dam, a large chestnut mare, of untraced blood. 
Planeroid, by Planet, out of Florence Nightingale, by O'Meara, son of Glencoe.

Bred by M. L. Nellums, Spring Hill, Tenn. Bought of him.

No. 91 .

INIX. Gray colt; foaled May 3, 1886, By Tom Hal, sire of Brown Hal, 2.13.

First dam Stella, by Geo. Washington (pacer).

Second dam Sweepstakes, by Knight's or Dudley's Snow Heel (pacer).

'Third dam Kit, by McMeens' Traveler (pacer).

Geo. Washington by Pointer's Slasher (pacer), dam Biddy, by Johnny Miller (quarter horse).

Snow Heel was by Knight's 'Tom Hal, son of Kittrell's Tom Hal.

McMeens' Traveler, by Sugg's Stump, son of Stump-the-Dealer, thoroughbred son of Timoleon.

I farmed the dam of Index from Capt. H. P. Pointer, Spring Hill, Tenn.

No. 92 .

P.A.MET TO. Brown colt, $15 \frac{1}{4}$ hands high, with left fore foot and right hind foot white, white speck in face; foaled March 28, 1886. By Brown Hal, 2.13.

First dam Maggie, by Enterprise, No. 2318, son of Enfield.

Second dam, by Bob, son of Stanfill's Traveler (pacer).

Third dam, by a son of Old Mountain Slasher (pacer).

Enterprise, by Enfield, 2.29; dam Betsey Trotwood, by Idol, sire of Don, $2.22 \frac{1}{2}$.

Stanfill's Traveler, by McMeens' Traveler, son of Stump-the-Dealer (thoroughbred), and he by Timoleon, sire of Boston. -

I farmed the dam of this colt from John Crow, Rally Hill, Tenn., who bred him, his dam, and his grandam.

No 93.

VIGILANT. Red roan colt, $15 \frac{1}{4}$ hands high, with large star in face; foaled March 29, 1886. By Tom Hal, sire of Little Brown Jug, $2.11 \frac{3}{4}$. 
First dam Bessie, by John Dillard Jr.

Second dam the "Cige Alexander Mare," a fast natural pacer, and producer of pacing speerl.

John Dillayd Jr., by John Dillard, sire of the dans of Phil Thompson 2.161, MeLeod, 2.251, Eric, 2.281, ete. The dam of John Dillard Jr. was by Bellfounder, second dam by Price's Messenger, third dam by. John Randolph. John Dillard Jr. was bred by a Mr. Headley, near Lexington, Ky., and brought to Maury County by Capt. Thos. (iil)son as a two-year-old. T'enn.

I farmed the dam of Vigilant from W. H. Brown, Spring Hill,

\section{No. 94.}

KOOKOO. Bay colt, with two white hind feet; foaled April, 1887. By Brown Hal, 2.13.

First dam Sweepstakes, by Knight's Snow Heel (saddle horse).

Second dam Kit, by McMeens' Traveler, grandsire of Joe Bowers .Jr., 2.18, and Sam Jones, 2.183.

Snow Heel (Knight's or Dudley's), by Knight's Tom Hal, son of Kittrell's Tom Hal.

Traveler, by Sugg's Stump, son of Stump-the-Dealer, thoroughbred son of Timoleon.

I farmed the dam of Kookoo from Capt. H. P. Pointer, Spring Hill, Tenn. She is a fast pacer for an untrained animal.

No. 95 .

PATASCO. Brown colt, solid, no marks; foaled April 7,1887 . By Brown Hal, 2.13.

First dam Yellow Mag, by Slasher (Pointer's) (pacer).

Second dam Fox, by Driver (pacer).

Third dam, by McMeens' Traveler (pacer), grandsire of Joe Bowers Jr.. 2.18, Sam Jones, $2.18_{4}^{3}$, ete.

Pointer's Slasher was a fast and handsome pacer, by Mountain Slasher, dam the great premium mare, Zephyr, by MeMeens' Traveler.

Driver was a fast-pacing black horse, owned by the late Allen T. Nolan, of Williamson County, Tenn. 
McMeens' 'Traveler was a strong, handsome chestnut, a fast pacer, by Sugg's Stump, soll of the thoroughbred Stump-the-Dealer, by Timoleon. The dam of McMeens' Traveler was a fast saddle mare of untraced blood.

Bred at Ewell Farm. His dam, Yellow Mag, is very fast for an untrained pacer.

No. 96.

PICKE'T'T. Bay colt, no marks; foaled April, 1887. By Brown Hal, 2.18.

First dam Annie, by Gibson's John Dillard Jr., son of John Dillard (saddle horse).

Second dam, by Thompson's Traveler (pacer).

John Dillard Jr. was by John Dillard, sire of the dams of Phil Thompson,

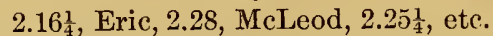

Thompson's Traveler, by McMeens' Traveler, sire of Joe Bowers, 2.32, and grandsire of Joe Bowers Jr., 2.18, and of Sam Jones, 2.18 $\frac{3}{4}$, dam by Blackman's Sir Charles, thoroughbred son of Sir Charles.

I farmed the dam of Pickett from Capt. H. P. Pointer, Spring Hill, Tenn.

\section{No 97.}

RUSTIC. Bay colt, with star, left hind foot white; foaled April, 1887. By Brown Hal, 2.13.

First dam Bessie, by John Dillard Jr.

Second dam the "Cage Alexander Mare," a fast natural pacer, and producer of pacing speed.

John Dillard Jr., by John Dillard, sire of the dams of Phil Thompson,

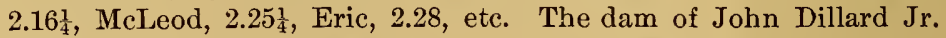
was by Bellfounder, second dam by Price's Messenger, third dam by John Randolph. John Dillard Jr. was bred by a Mr. Headley, near Lexington, Ky., and brought to Maury County by Capt. Thos. Gibson as a two-year-old.

I farmed the dam of Rustic from W. H. Brown, Spring Hill, Tenu. 
No. 98.

SIMPLEX. Bay colt, no star, left fore foot white; foaled in 1887. By Duplex, 2.17市.

First dam Fanny, by Norton (son of Lexington).

Second dam, a pacer.

This colt was bred by J. W. Story, West Harpeth, Tenn., of whom I bought him. His dam was bred by N. H. Russell, who sold her to story.

No. 99.

S'TORM. Black colt, no star, heel of left hind foot white; foaled April, 1887. By Brown Hal, 2.13.

First dam Zephyr, by Jameson's John Dillard Jr., grandson of John Dillard.

Second dam Tampa, by Thompson's Traveler (pacer).

Third dam, by Nolan's Old Copperbottom (pacer).

Fourth dam, by Ridley's Medley.

Fifth dam, by a horse called Eclipse.

Sixth dam, brought by him from Kentucky in 1832, by the late Mr. William Witt, of Spring Hill, Tenn.

John Dillard, grandsire of Jameson's John Dillard Jr., sired the dams of

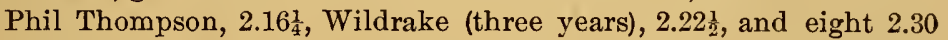
trotters.

Thompson's Traveler sired Sam Jones, 2.183.

I farmed the dam of Storm from W. H. Brown, Spring Hill, Tenn. 


\section{ROADSTERS, SADDLE MARES, AND GELDINGS.}

No. 100.

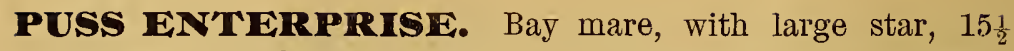
hands high; foaled in 1879. By ENTERPRISE, son of ENFIELD, 2.29 .

First dam Puss Denmark, by Harris' Denmark.

Second dam, by Warfield's Sidi Hamet.

Enterprise was by Enfield, 2.29, out of Betsy Trotwood, by Idol. See Betsey Trotwood, No. 5, for extension of pedigree.

Puss Denmark was one of the handsomest and most highly finished saddle mares and prize winners ever in Tennessee. It is said she was never beaten in a show ring. At Nashville and Columbia she won in her class and in sweepstakes, and at Columbia a special premium for best mare and three of her foals. Her pedigree, as stated here, is that given by her previous owner, Dr. Rife, of Kentucky, to Capt. Gibson, breeder of Puss Enterprise, and is doubtless correct.

This is a remarkably handsome mare, broken to harness and saddle.

No. 101.

LADY K. Chestnut mare, with star and two white feet, $15 \frac{1}{4}$ hands high; foaled in 1883 . By ALMONT JR., 2.29, sire of Annie W., 2.20.

First dam Annie K., record 2.40.

Lady K. was bred by V. L. Kirkman. She is a handsome, lengthy animal, strongly disposed to pace in harmess, very gentle, and a good saddle mare.

No. 102 .

DUDE. Brown gelding, $15 \frac{1}{2}$ hands high; foaled in 1882 . By Samuel J. Tilden (pacer).

First dam Combination (thoroughbred), by Brown Dick. Second dam Chance, by Everlasting, son of Highlander. Third dam, by Hannibal, son of Priam. 
Fourth dam Prunella, hy Imported Priam.

Fifth dam Preminm, by Imported Consol.

Sixth dam Imported Allegra, by Woful.

Seventh dam Allegretta, by Trumpetor, ete.

Dude was bred by $\Lambda$. F. Brown, Columbia, Tenn. He is a horse of high style, a good driver, walks, fox-trots, and canters well, and has rum a mile, with $155 \mathrm{lbs}$. up, in 1.56 over my track. He was used during 1887 as a runner, with Brown Hal, and is a sensible, spirited, active horse.

No. 103.

OPTIMIST. Chestuut gelding, 16 hands high, with three white legs and comet-shaped star in forehead; foaled April 6, 1884. By Tennessee Wilkes.

First dam Ada Brungard (dam of Optima, two-year record 2.54 year record 2.48), by Black Hawk Rattler.

Second dam Gamma, by Frank IIcNairy.

For Tennessee Wilkes' pedigree see No. 1.

Black Hawk Rattler by Biggart's Rattler, sire of the dams of four 2.30 trotters, and grandsire of Joe Brown 2.22. The dam of Black Hawk Rattler was Dairy Maid (dam of Tennessee, 2.27), by Vermont Black Hawk, sire of Ethan Allen.

I farmed the dam of Optimist from Dr. J. T. S. Thompson, Spring Hill, Tenn. Her daughter, Optima, has started in three races, winning all, and as a four-year-old trotted a trial on my track in $2.22 \frac{1}{2}$. Optimist himself is very fast. He trotted as a three-year-old a trial in 2.39 on my track; and would have gone much faster but had to be let up on account of an attack of pinkeye.

No. 104.

TURK. (Standard.) Brown gelding, 15 $\frac{1}{2}$ hands high, with star and two white hind ankles; foaled in spring of 1885. By Tennessee Wilkes.

First dam Blackmaid, hy BLAckwoon JR., 2.22! .

Fecourd dam Belle of Burlington, by Brown Dick (thoroughbred). 
Third dam Milkmaid (dam of Josephine, 2.32), by Biggart's Rattler. Fourth dam Dairy Maid (dam of Tennessee, 2.27), by Vermont Black Hawk.

Bred by Jas. L. Cooper, Nashrille, of whom I bought him. Fast natural pacer.

No. 105.

BONNIE WILKES. (Standard.) Bay gelding, $15 \frac{1}{4}$ hands high; foaled in 1885. By Tennessee Wilkes.

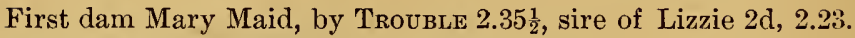

Second dam Bonnie Maid, by Enfield, 2.29.

Third dam Belle of Burlington, by Brown Dick (thoroughbred).

Fourth dam Milkmaid (dam of Josphine, 2.32).

Fifth dam Dairy Maid (dam of Tennessee, 2.27), by Vermont Black Hawk.

Bred by Jas. L. Cooper, Nashville, of whom I bought him.

No. 106.

TENANT. Bay gelding with left hind heel white, very dim star in forebead; foaled May, 1886. By ENFIELd, 2.29.

First dam Roan, by Tom Hal, sire of Brown Hal, 2.13, and Little Brown Jug, 2.113.

Second dam, by Pointer's Slasher (pacer).

Enfield (sire of two 2.30 horses), by Rysdyk's Hambletonian (sire of forty horses with records of 2.30 or better). First dam Julia Machree (full sister to Widow Machree, 2.29), by Seely's American Star. His breeding is identical with that of Dictator, Startle, and:Aberdeen.

Pointer's Slasher, by Old Mountain Slasher, out of the noted premium mare, Zephyr, by McMeens' Traveler, sire of Joe Bowers, 2.32, and grandsire of Joe Bowers Jr., 2.18, and of Sam Jones, 2.18

I farmed the dam of this gelding from Mr. John A. McMeeus, of Carter's Creek, Tenn. 


\section{ASHWOOD FARM STOCK.}

Note. - Ashwood Farm is at Ashwood (postoffice and railway station), seven miles west of Columbia, in Maury County, Tennessee. It is held under lease by Campbell Brown and W. Polk, under the partnership name of Brown \& Polk. The firm is engaged in breeding and dealing in trotting and pacing horses. All inquiries as to the animals contained in this portion of the catalogue should be addressed to Major W. Polk, Ashwood P. O., Maury Co., Tenn.

\section{STALLIONS IN USE.}

No. 107.

BRIGHTON, No. I5Io. Brown stallion, $15 \frac{3}{4}$ hands high, with wine-colored muzzle and flanks; foaled in 1880. Bred by E. G. Doolittle, New York. By Harry Clay, No. 45 (record 2.29).

First dam Vivandere (sister to Goldsmith's Abdallah, record 2.30), by Volunteer, No. 55.

Second dam Martha, by Abdallah, No. 1.

Third dam, by Conklin's Bellfounder, son of Imp. Bellfounder.

Fourth dam, by Corncracker.

Fifth dam, by Hickory.

The extraordinary richuess of this pedigree speaks for itself. The Clay blood has never been in such demand as at this time, and no Clay stallion can claim more fashionable or more desirable breeding than Brighton. $\mathrm{He}$ is by the sire of that greatest of brood mares, Green Mountain Maid, dam of Electioneer, and of six 2.30 horses; and his dam is by Volunteer, son of Hambletonian, and sire of St. Julien, 2.111, and of twenty-six 2.30 horses. His grandam is the speed-producing mare Nartna, by Old Abdallah, sire of Hambletonian. 
Brighton is the property of his breeder, Mr. E. G. Doolittle, of New York. We consider ourselves fortunate in being able to offer his services for 1888 , at a very reasonable figure, to the breeders of Tennessee. He is handsome, stylish, strong-limbed, thoroughly sound, nice-tempered, and can show a good deal of speed, with a good way of going.

Stands at $\$ 35$ to insure.

No. 108.

SHR WILKES, 3328. Chestnut stallion; foaled August 6, $1884 ; 15 \frac{1}{2}$ hands high. Bred by E. D. Herr, Lexington, Ky. By YodNG Jim, son of Geo. WrLkes, 2.22, and sire of Garnet, 2.19, and Butterfly, 2.193.

First dam Mary Mays, by Mambrino Patcien, No. 58.

Second dam, by Sarpedon.

Tiird clam, by Copperbottom.

Fourth dam, by Woodford.

Fifth dam, by Bay Messenger, by Harpinus Son.

Young Jim is by George Wilkes, sire of sixty-one 2.30 horses, ont of the dam of Jim Irving, 2.23, by Lear's Sir William.

Mambrino Patchen sired London, 2.20, and fourteen other 2.30 horses. No less than eighteen of his sons have sired 2.30 trotters, and while his daughters are in the very first rank as brood mares, their greatest success has been when crossed with the blood of George WVilkes.

The dams of Guy Wilkes, 2.15⿺𠃊丶万 Anglin, Wilkes Boy, Cleora, Bermurla, etc., were by Mambrino. Patchen.

Sir Wilkes is a beautiful red chestnut in color, handsome, strong, and finely gaited, with excellent natural speed.

Stands at $\$ 20$ to insure. 


\section{BROOD MARES.}

No. 109.

ALMA. Dark bay mare; foaled in 1882. Bred by W. R Letcher, Richmond, Ky. Sired by St. Almo, son of Almont.

First dam Bell, by Indian Chief.

Second dam a fine saddle mare.

Alma is broken to harness, nearly 16 hands high, and goorl gaited.

Bred to Brighton, No. 1510.

No. 110.

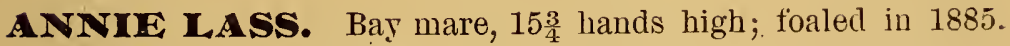
Bred by S. P. Walters. By Hylas, No. 831, record 2.24t.

Dam a fine combined mare.

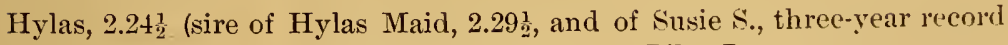
2.20), is by Alcalde; dam Santa Maria, by Pilot Jr.

Alcalde (sire of four 2.30 horses), by Mambrino Chief, rlam by Pilot Jr.

Bred to Brighton, No. 1510.

No. 111.

BETTY MARTIN. (Standard.) Bay mare, $15 \frac{3}{4}$ hands high; foaled in 1882. Bred by W. \& V. L. Polk. By Exfield, No. 128 , record 2.29 .

First dam Madam Dumcan, by D.irlbay, No. 441, recorl 2.40.

Second dam, by Old Harry (pacer).

Third dam, by a Cleveland bay stallion.

Fourth dam thoroughbred.

Enfield, 2.29, by Rysdyk's Hambletonian, dam Julia Machree, by American Star.

Darlbay, sire of Lady Thorn Jr., 2.25, and R. F. C., 2.23\}, is ly Mambrino Patchen, dam Puggie, by Brignoli, 2.293. 
No. 112.

BL,ACK BELLE. Black mare, 16 hands high; foaled in 1884. Bred by S. P. Walters, Lexington, Ky. By HYlas, No. 831, record $2.24 \frac{1}{2}$.

Dam the dam of Annie Lass, No. 108.

Hylas, $2.24 \frac{1}{2}$ (sire of Susie S., three-year record 2.20, and Hylas Maid, $\left.2.29 \frac{1}{2}\right)$, is by Alcalde, dam Santa Maria, by Pilot Jr.

Bred to Brighton, No. 1510.

No. 113.

CAMILLA. (Standard.) Bay mare; foaled in 1880 . Bred by James McKee, Cynthiana, Ky. By Harrison ChIEF, No. 3841.

First dam, by Joe Downing, No. 710 .

Second dam, by Shawhan's Vandal.

Harrison Chief (sire of George L. 2.26 $\frac{1}{2}$ ), by Clark Chief, sire of Croxie, 2.19 , dam by Joe Downing.

Joe Downing (sire of Abe Downing, 2.20 Edwin Forrest (Alexander's), dam Lizzie Peeples by Wagner.

Bred to Ethan Wilkes, son of George Wilkes.

No. 114.

CURRENT. (Standard.) Brown mare, foaled in 1885. Bred by W. R. Kerr, Middletown, Ky. By Cdrrencr, No. 3709.

First dam by Westwoov, No. 2363.

Second dam the dam of Jenny Strideaway, trial 2.24, by a son of Tom Crowder.

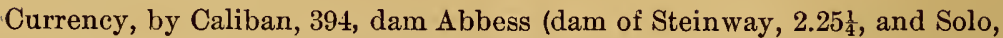
$2.28 \frac{1}{4}$, and Soprano), by Albion.

Caliban (record 2.34), sire of C. F. Clay, 2.18, Cyclone, $223 \frac{1}{2}$, by Mambrino Pilot, (saddle record 2.27), sire of Hannis, 2.17 $\frac{3}{4}$, Mambrino Gift, 2.20, dam by Cassius M. Clay Jr.

Westwood, by Blackwood, sire of Proteine, 2.19, etc., dam Favorite, by Alexander's Abdallah, second dam the dam of Joe Downing and Jim Monroe.

Bred to Ethan Wilkes. 
No. 115.

ENFILADE. Bay mare, no marks, 15 hands high; foaled in spring of 1883. By ENFIELD, 2.29.

First dam Chieftain's Daughter, by Chieftain, $2.353_{4}^{3}$.

Second dam Lee Belle, by Lee, son of Mambrino Chiei.

Third dam BeLre Sheridan (dam of Blackwood Jr., 2.22k), hy Blood's Black Hawk.

Fourth dam, by Moreland's Highlander.

Fifth dam, by Virginia Whip.

Enfield, by Rysdyk's Hambletonian, sire of forty horses in 2.30 list, danı Julia Machree, full sister to Widow Machree, 2.29, by American Star. Enfield is bred like Dictator and Startle, and is full brother in blood to Aberdeen.

Chieftain (Overton's) was by Clark Chief, sire of the dams of Phallas, $2.13 \frac{3}{4}$, Majolica, 2.15, etc.

Lee Belle was a remarkable show mare. She won first premium at St. Louis Fair in a ring of sixty-five roadsters, mares, and geldings, getting every vote.

Enfilade was bred by John Overton, Esq., Nashville, Tenn., of whom we purchased her.

No. 116.

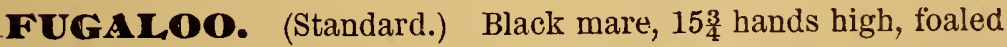
in 1881. Bred by S. F. Woodson. By MARS, No. 2775, son of Jupiter.

Dam by Harry Clay, No. 45, record 2.29.

Second dam, by Iron Duke.

Mars, by Jupiter, dam by Rysdyk's Hambletonian.

Jupiter (sire of four 2.30 horses and of the dams of five others), by Long Island Black Hawk, sire of two 2.30 horses and of the dams of three others. Jupiter's dam was by Almack, son of Mambrino.

\section{PRODUCE.}

1887-Black filly, Fernleaf, by Black Cloud, 2.171.

Bred to Nuthill, No. 4674, son of Nutwood, $2.18 \frac{3}{4}$. 
No. 117.

GUERRILLA. Bay mare, $15 \frac{1}{2}$ hands high; foaled in 1880 . Bred by Geo. M. Jewett, Zanesville, Ohio. By Almont Chief, No. 361.

First dam Lucy Luby, by Dolphin, son of Pataskala.

Second dam Guerrilla. (Dr. Herr says she can pace in 2.22.)

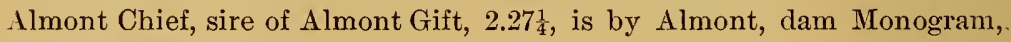
by Mambrino Chief.

PRODUCE.

1886- b. f., Guerretta, by Arnold, No. 966.

1887-Missed to Allendorf.

Bred to Brighton, No. 1510.

No. 118.

HALIRIRO OK. Roan mare, foaled in 1880. Bred by Charles Orr, Marshall County, Tenn. By Tom Hal, sire of Little Brown Jug, 2.113, and Brown Hal, 2.13.

First dam by Brooks, sire of Bonesetter, 2.19.

Second dam by Stump.

Bred to Brighton.

No. 119.

M MRY ELLMORE. (Standard.) Dam of Cleveland, 2.28. Bay mare, $15 \frac{1}{2}$ hands high; foaled in 1864 . By MAMBRUNelio, No. 221 (sire of Tom Britton, 2.26, and Sadie Howe, 2.26), son of MaMbrino Chief.

First dam, by Star Davis (thoroughbred).

Second dam, by Old Copperbottom (pacer).

Mambrunello, by Mambrino Chief, first dam by Hunt's Commodore, sec-. ond dam by Gray Eagle, third dam Lady Adams by Whisper, fourth dam Woodpecker's dam by Buzzard.

Mary Ellmore was bred by Joel Adkins, Versailles, Ky. Her son, Cleveland, has a record of 2.28, and was a grand show horse, having taken a number of premiums in Kentucky. We are unable. to give a complete list of ber foals. Those since she has been in Tennessee are: 


\section{PRODUCE.}

1880-b. i., Armeda, by Commissioner.

1881-b. í., Glide, by Enfield.

1882-b. c., May Overton, by Enfield.

1883-b. c., Elmore (gelded), by Enfield.

1884-b. f., Sehoya, by Tennessee Wilkes.

1885-b. f., by Tennessee Wilkes.

1886-b. f., by Tennessee Wilkes.

1S87-b. c., by Enwood, son of Enfield. " (Sold.)

Bred to Brighton, No. 1510.

No. 120 .

MAUD H. Roan mare, $15 \frac{1}{4}$ hands high; foaled in 1879. By WOODS' HaMbleTONIAN, No. 572.

Dam by the Murrell Horse.

Woods' Hambletonian (sire of sixteen horses in the 2.30 list), by Alexander's Abdallah, sire of Goldsmith Maid, 2.14.

Bred to Brighton, No. 1510.

No. 121.

MOLLIE H. Chestnut mare, $15 \frac{1}{2}$ hands high; foaled in 1884 . Bred by E. Higgins, Maury County, Tenn. By Enfield, No. 128 , record 2.29 .

First dam, by Hunter's Clipper (pacer).

Second dam, a good road mare.

Bred to Brighton, No." 1510.

No. 122.

NELLIE. (Standard.) Bay mare, $15 \frac{1}{4}$ hands high; foaled in 1877. Bred by Wm. McClintock, Millersburg, Ky. By JoE DoWNing, No. 710 .

First dam Belle, by Indix Chref, No. 832.

Second dam, a fine saddle mare.

Joe Downing (sire of Abe Downing, 2.201, and Dick Jamison, 2.26, also of four producing dams), is by Alexander's Edwin Forrest, dam Lizzie Peeples, by Wagner. 
Indian Chief (sire of Warrior, 2.26, and the dam of Ophelia, 2.30), by Blood's Black Hawk, dam Lou Berry, by Ned Forrest.

Bred to Brighton, No. 1510.

No. 123.

PRINCESS HAI. Roan mare; foaled in 1884. Bred by D. F. Watkins, Maury County, Tenn. By Tom Hal, sire of Brown Hal, 2.13.

First dam, by Prince Pulaski, sire of Mattie Hunter, 2.123.

Second dam, by Commodore, thoroughbred son of Boston.

Bred to Brighton.

No. 124.

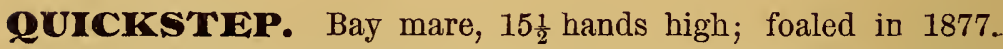
Bred by Henry Buckner, Paris, Ky. By Kentucky PRince JR., sire of J. Q., $2.17 \frac{1}{2}$.

First dam, by Skinner's Old Joe (pacer), sire of the dam of J. Q., 2.171.

Kentucky Prince Jr., by Kentucky Prince, dam by Mambrino Patchen. He is the sire of J. Q., 2.17 2 .

Kentucky Prince, by Clark Chief, dam by Morgan Eagle. He is the sire of Spofford, $2.19 \frac{1}{2}$, and three other 2.30 horses, and the grandsire of four others.

No. 125.

RUSTLE. (Standard.) Bay mare, $15 \frac{1}{4}$ hands high; foaled in 1884. Bred by R. K. Polk. By Enfield, No. 128, record 2.29.

First dam Tornado Belle, 2.33 $\frac{1}{2}$, by Young Tornado.

Second dam, by Mambrino Chief, No. 11.

Enfield, 2.29, by Rysdyk's Hambletonian, dam Julia Machree, by American Star.

Young Tornado, by Tornado, dam by Sir Henry; second dam by Bishop's Hambletonian (son of Messenger); third dam by Magnum

Bonum. Tornado, sire of Young Tornado, by American Eclipse out. of a thoroughbred mare.

Mambrino Chief is the founder of the Mambrino Chief family.

Bred to Brighton, No. 1510. 
No. 126.

SYLYIA. Bay mare, $15 \frac{1}{2}$ hands high; foaled in spring of 1885. By SKePtic, No. 1509.

Dam by Chieftain, record $2.35 \frac{1}{2}$.

Skeptic is by Woodford Mambrino, sire of eleven horses in 2.20 list, out of Grace, by Pilot Jr., sire of the dams of Jay-Eye-See, 2.10, and Maud S., $2.08 \frac{3}{4}$.

Chieftain, record $2.35 \frac{1}{2}$, by Clark Chief, sire of seven 2.30 horses, and of the dams of Phallas, 2.133, Majolica, 2.15, and three 2.30 horses.

Sylvia was bred by John Overton, Esq., Nashville, of whom we bought her.

No. 127.

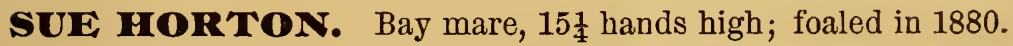
Bred by Thos. Gibson, Spring Hill, Tenn. By ENTERPrIse, No. 2318.

Dam Rachel Horton, $2.45 \frac{3}{4}$, by a son of Tippoo.

Enterprise, by Enfield, 2.29, dam Betsey Trotwood, by Idol, sire of Don,

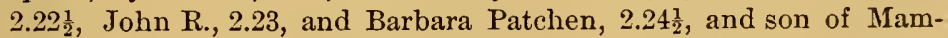
brino Chief.

Bred to Sir Wilkes, No. 3328.

\section{FILLIES.}

No. 128.

AMBER. Brown filly; foaled in 1885. Bred by Robert C. Estill, Lexington, Ky. By ABDalbrino, No. 2646.

First dam Peggy, by Cromwell (pacer).

Second dam, by Justin Morgan, No. 2234.

Third dam, by Perfection.

Fourth dam, by Davy Crockett (Cromwell's). 


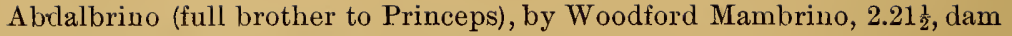
Primrose, by Alexander's Abdallah.

Justin Morgan (sire of Lady Lowe, 2.28, and Wick, 2.26를), by Lowe's Comet Morgan, dam by Downing's Bay Messenger, sire of Jim Porter, record to saddle 2.28.

Amber's dam, Peggy, is the dam of the three-year-old pacer, Speculator, that, in a race at Maysville, $\mathrm{Ky}$., last fall, paced the last half of the mile in $1.08_{2}^{1}$.

No. 129.

ANNIE DICTATOR. Bay filly; foaled in $1886 . \quad$ Bred by George Fitzhugh, of Kentucky. By Dictator, JR.

First dam, by Stockdale's Dillard, by John Dillard, sire of the dam of Phil Thompson, $2.16 \frac{1}{2}$.

Second dam, by Melbourne Jr.

Third dam, by J. C. Breckinridge.

Dictator Jr., by Dictator (sire of Jay-Eye-See, 2.10, Phallas, 2.13 $\frac{3}{4}$ ), dam Snowbird (dam of Mist, 2.2912), by Snowstorm (pacer).

Dictator (brother to Dexter $2.17 \frac{1}{4}$ ) by Rysdyk's Hambletonian, dam Clara by American Star.

Melbourne Jr. (thoroughbred) sired the dams of J. W. South, 2.291, and Clermont, 2.30 .

No. 130.

GUERRET'TA. (Standard.) Brown or bay filly, foaled in 1886. Bred by Dr. L. Herr, Lexington, Ky. By ArNold, No. 966.

Dam Guerrilla, by Almont Chief, No. 361.

Second dam Lucy Luby, by Dolphin, son of Pataskala.

Third dam, Guerrilla, that Dr. Herr says can pace in 2.22 .

Arnold, by Goldsmith's Abdallah, record 2.30, dam Sally Neal (dam of

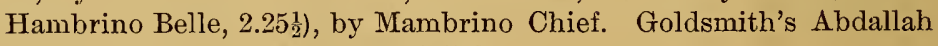
by Volunteer, dam by Old Abdallah.

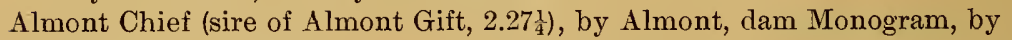
Mambrino Chief.

Almont by Alexander's Abdallah, dam by Mambrino Chief, second dam by Pilot Jr. 
No. 131.

ISIS. (Standard.) Bay filly; foaled in 1886. Bred by Col. John Overton, Nashville, Teun. By Rembrandt, trial 2.26.

First clam Iris, by Chieftain, record $2.35 \frac{1}{2}$.

Fecond dam Ineve (dam of Hardwood, record $2.24_{4}^{3}$ ), by Colcusus, sire of Little Mack, 2.28?.

The dan of Irene was a large brown mare, bought by A. J. McKimmin in a drove at Cincinnati; a plain, strong mare, of good trotting action but of unknown blood.

Rembranrlt by King Rene, dam l,y Regular, son of Volunteer.

Chieftain, record $2.35 \frac{1}{2}$, by Clark Chief, sire of seven 2.30 horses and of the dams of Phallas, $2.13_{4}^{3}$, Majolica, 2.15 , and three 2.30 horses.

Columbus, sire of Little Mack, 2.283, was by Brown's Bellfounder, he by Imp. Bellfounder ont of Larly Allport, by Mambrino.

No. 132 .

MISS ELMORE. (Standard.) Bay filly; foaled in 1886. Bred by Brown \& Polk. By Tennessee Wilkes, No. 2735.

First dam Mary Elmore (dam of Cleveland, 2.28), by Mambrúnello, No. 221.

Second dam, by Star Davis, (thoroughbred).

Third dam, by Old Copperbottom (pacer).

Tennessee Wilkes, trial 2.25, by George Wilkes, 2.22, dam Lizzie Hayden, by Peavine, No. 513, sire of Nettie Ward, 2.29 and Lucy Fleming, 2.24 .

Viambrunello (sire of Sadie Howe, 2.26), y Mambrino Chief, dam by Hunt's Commodore.

No. 133.

STAR KATE. (Standard.) Bay filly, star, hind ankles white; foaled 1886 ; bred by E. G. Bedford. Sired by VICTOR VoN Bismarck, No. 326, sire of Kentucky Hambletonian, 2.27 (Owu brother to GAZELLE, 2.21).

First dam Kate Joe, by Joe Dowrixg, No. 710, sire of Abe Downing, 2.203. Second dam Kate Rattler, by Morgan Rattler, sire of the dam of Endymion, 2.231.

Third dam Kate Chief, by Canala Chief, sire of the dam of Coaster, 2.261. Fourth dam Kate. 
Victor Von Bismarck is sire of Kentucky Hambletonian, four-year record 2.27, Edgemarck, two-year record 2.33, and a number of promising young trotters. He is brother in blood to Electioneer, both being by Hambletonian, out of speed-producing daughters of Harry Clay.

Joe Downing, by Edwin Forrest, out of the dam of Jim Monroe, by Wagner. He sired Abe Downing, 2.20 3 , Dick Jamison, 2.26, and the dams of Lorene, 2.15⿺ and four other 2.30 horses.

Star Kate is bred like Kentucky Hambletonian, 2.27, both being by Bismarck, out of mares by Joe Downing.

No. 134.

WANDA. (Standard.) Bay filly; foaled in 1886. Bied by Brown \& Polk. By Tennessee Wilkes, No. 2735.

First dam Melrose (three-year trial 2.31), by: Auministrator, No. 357, record $2.29 \frac{1}{2}$.

Second dam Mattie Price, record 2.29, by Woodford Mambrino, No. 345, record 2.21.

Third dam Miss Taylor, by IDou, No. 177, record $2.41 \frac{3}{4}$ at four years.

Fourth dam Carrie D (thoroughbred), by Don Juan.

Fifth dam Romance (thoroughbred), by Sir Leslie.

Sixth dam, by Trumpetor.

Seventh dam Mary Jones, by Kosciusko.

Eighth dam, by Young Bedford.

Ninth dam, by Iron.

Tenth dam, by Brilliant.

Adminstrator, $2.29 \frac{3}{4}$ (sire of Catchfly, $2.18 \frac{1}{4}$, and three others in 2.30 list), by Rysdyk's Hambletonian. Dam Dolly Holstead, by Mambrinó Chief.

Woodford Mambrino, 2.21 (sire of Abbotsford, 2.191 , and ten others in 2.30 list), by Mambrino Chief. Dam Woodbine, by Woodford.

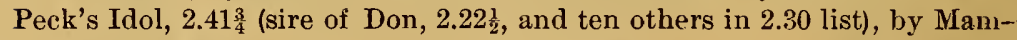
brino Chief. Dam, by American Eclipse. 


\section{PONIES.}

A part of the farm being hilly and well adapted to rearing pouies, I have established a herd of about sixty, headed by the imported Welsh stallion, Rajah, and the Shetland stallion, Dandythe former $13 \frac{1}{2}$ and the latter $9 \frac{1}{4}$ hands high. The mares are Welsh, Shetland, aul Creole, or Acadian. These are a native breed, formed in the Attakapas region in West Louisiana, and well known for docility, endurance, and actirity. They are totally distiuct from the ponies of 'Texas or Mexico, and are admirably suited for boys $\mathrm{or}^{\circ}$ girls from ten to tifteen years of age.

They have clean limbs, bony heads, neat crests, good sloping shoulders and strong backs, but are apt to be a little flat-ribbed and ragged-hipped. To remedy this, which seems their only defect, they are being crossed with the rounder Welsh and Shetland, with promise of excelleut results. None of the crossbreeds are ready for the market, the oldest being two years old.

\section{JERSEY CATTLE.}

'The Ewell Farm herd numbers about one hundred and fifty head, including many noted animals.

It is headed by Imp. Tormentor, 3533, only living son of Khedive, and sire of fifteen cows with tests ranging from 14 lbs. to 23 lbs. $2 \frac{1}{2}$ oz. per week. The other bull in use is Ida's Stoke Pogis, whose full brother, Ida's Rioter, stands at $\$ 1,000$ in the herd of Messrs. Miller \& Sibley. The herd contains over thirty tested cows, the dams of about thirty others, and the daughters of tifteeu others.

Young stock always for sale.

\section{SHEEP AND PIGS.}

The flock of Southdowns numbers about one hundred. Berkshire pigs are bred for sale from animals impurted by the owner from the noted herd of Heher Humfrey, Esq., Abingdon, England. 


\section{TERMS FOR KEEPING STOCK.}

Brood mares $\$ 3.00$ per month on grass, $\$ 8.00$ per month wheu fed, or $\$ 60.00$ per year. This includes stabling during the winter, and the same attention, in all respects, that is given my own stock.

Weanlings, regardless of sex, from September 1st to May 1st, $\$ 8.00$ per month. This includes weaning and halter-breaking. Yearling stallion colts from May 1st, $\$ 12.00$ per month. Twoyear-old stallions, after May 1st, kept only by special contract. Fillies in yearling or two-year-old form kept on same terms as brood mares.

\section{TERMS OF BREEDING.}

Season begins February 15th and ends August 1st. Good care taken, but no responsibility for accidents or escapes. Mares not proving with foal can be returned free of charge NEXT YEAR, unless. otherwise contracted. TERMS, CASH AT TIME OF SERVICE. 


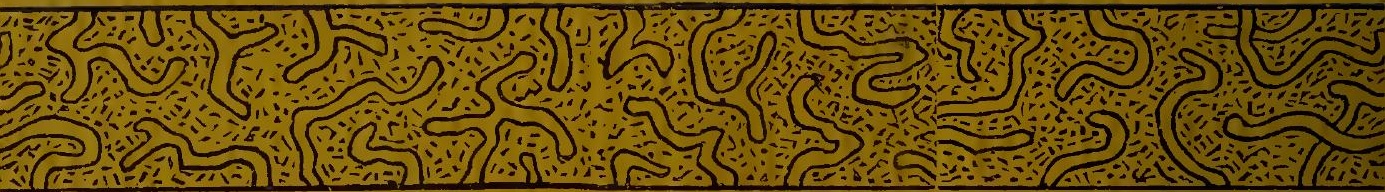

\section{Annual Public Sales}

Hereafter, the Annual Public Sales of Trotting and Pacing Horses and Jersey Cattle belonging to Ewell Farm will take place on the

\section{$\underline{\text { Last Wednesday in IMay }}$}

of each year, and Catalogues of the stock to be offered will be ready for distribution by the middle of April.

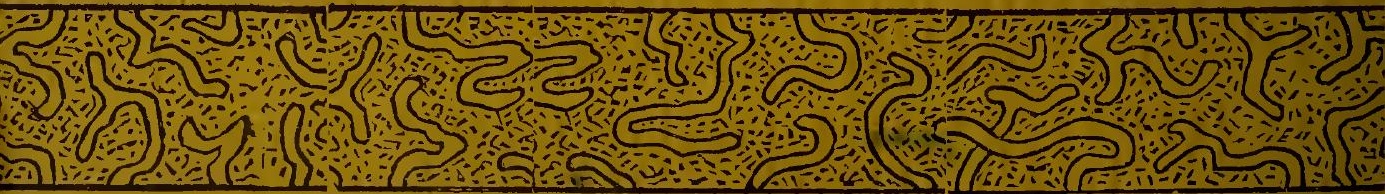

